\title{
The Characteristics of Habitat, Functional Traits and Medicinal Components of Eucommia Ulmoides From Guizhou
}

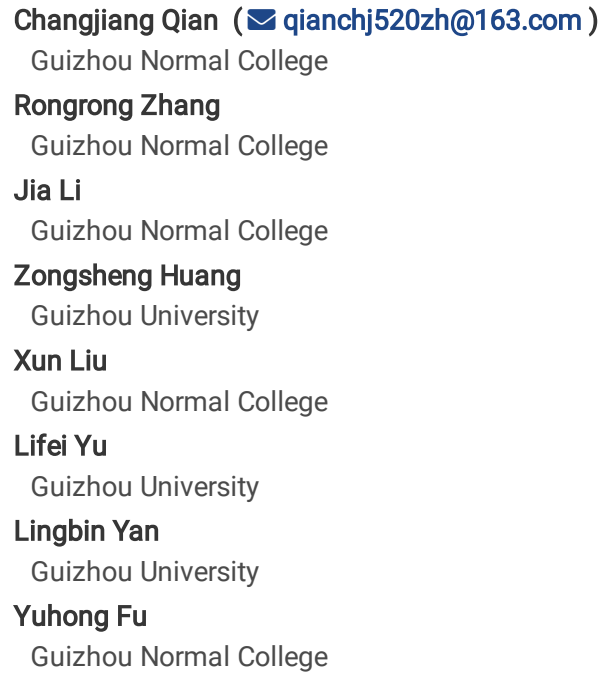

Version of Record: A version of this preprint was published at Environmental Science and Pollution Research on August 31 st, 2021. See the published version at https://doi.org/10.1007/s11356-021-15596-6. 


\section{Abstract}

To find out the genuine characteristics of Eucommia ulmoides produced in Guizhou. The habitat, functional characters and the content of medicinal components of Eucommia ulmoides in Guizhou were studied by using the method of sample survey combined with typical survey, related laboratory experiments and quantitative analysis. The results showed that the yield of Eucommia ulmoides plantation in Guizhou was divided into low altitude, low middle and high temperature rain slope latitude mixing, short sunshine type(A type), medium altitude, low longitude and latitude, high temperature rain, positive oblique steep slope, medium sunshine type (B type), Middle altitude, low longitude and latitude, moderate high temperature rain, Shady side and Sunny side have gentle deflection steep slope, medium sunshine type ( $\mathrm{C}$ type), High altitude, low longitude and latitude, low temperature moderate rain, positive gentle slope, long sunshine type ( $\mathrm{D}$ type); Different types of Eucommia ulmoides plantation, Different habitat quality, B type is intensity karst rocky desertification habitat, A type is potential karst rocky desertification habitat, The $C$ and $D$ types are light and moderate rocky desertification areas respectively, The species diversity of shrub layer in Eucommia ulmoides plantation was higher in D type and B type, A type and C type followed; There was no significant difference in root carbon content and leaf nitrogen content in 4 types of Eucommia ulmoides plantation, Among the four types of $A \llbracket B \backsim C \square D$, there were significant or extremely significant differences in other indexes of plant functional traits; Both genipinic acid and aucubin had the highest content of root bark, followed by trunk bark and lowest leaves, Chlorogenic acid is the opposite, The content of geniposide was higher in trunk bark and lower in root bark and leaves; Genipinic acid is higher in D type, Aucubin is higher in A and D type, Chlorogenic acid has higher leaves content in B type, Geniposide was the highest in trunk bark of $\mathrm{D}$ type; The element enrichment coefficient $\mathrm{K}$ and Mn leaves are the largest, the largest in trunk bark is Ca and Zn, Fe root bark is the largest; Effects of soil potassium, phosphorus, $\mathrm{pH}$ value and bulk weight on the functional traits of Eucommia ulmoides were significant. The contents of medicinal components in root bark, trunk bark and leaves was influenced by species diversity of shrub layer, The contents of geniposide in root bark, aucubin in root bark and trunk bark, genipinic acid in bark and chlorogenic acid in leaves were particularly affected by soil physical and chemical indexes and metal element contents, The functional traits of Eucommia ulmoides can affect the content of medicinal components in root bark, trunk bark and leaves, Especially on the root bark, trunk bark and leaves in the content of aucubin content; The content of medicinal components of Eucommia ulmoides was high and stable. The above research results have important theoretical reference significance for the cultivation of Eucommia ulmoides and the cultivation of target medicinal components and the comprehensive exploitation and utilization of resources.

\section{Introduction}

Eucommia ulmoides is a mono-species genus deciduous tree unique to China, which is a rare and precious medicinal material unique to China, also a new type of pharmaceutical and food resource with antihypertensive effect (Bai, 2015; Zhu and Sun. 2018). Its medicinal components have anti-diabetic, antiinflammatory, antihypertensive and diuretic(Peng and Li, 2013; Sugawa et al., 2016; Wang et al., 2016; Hirata et al., 2011), anti-virus (Sun et al., 2004), hepatoprotective and choleretic (Lou et al., 2011) effects, which can alleviate hyperuricemia (Fang et al., 2019), treat non-alcoholic fatty liver disease (Lee et al., 2014), treat male sexual dysfunction caused by diabetes (Fu et al., 2019). At present, the planting area of Eucommia ulmoides in the country is about 5 million mu, accounting for more than $99 \%$ of the total in the world. The planting areas are mainly concentrated in Guizhou, Hunan, Sichuan, Hubei, Shaanxi, Henan, Chongqing, Gansu, Anhui, Jiangxi, etc., with an annual output value of 1 trillion yuan (Zhu, 2019; Du, 2020). Eucommia ulmoides plantations of Guizhou are mainly distributed in Zunyi City, Liupanshui City, Anshun City, Bijie City, Qiannan Prefecture and Qianxinan Prefecture. As of the end of 2013, the total area of artificial and wild Eucommia ulmoides in Guizhou Province reached $36,500 \mathrm{hm}$, accounting for $10.3 \%$ of the total area of Eucommia ulmoides in the country. The total output and total output value reached 50,000 tons and 27 million yuan respectively (Chen et al., 2015). Moreover, Eucommia ulmoides is listed as one precious medicinal material out of ten genuine medicines in Guizhou (He et al., 2005; Wu, 2015). Therefore, systematic research on the genuine medicinal material Eucommia ulmoides produced in Guizhou carries important theoretical and practical significance for the economic and social development of Guizhou and the cultivation of eucommia ulmoides in Guizhou area.

At present, research of Eucommia ulmoides mostly focuses on its pharmacology and effects (Wang et al., 2015; Fang et al., 2015; Du, 2003), medicinal component characteristics and influencing factors (Zhang et al., 1999; Liu et al., 2015; Wang, 2008; Cai et al., 2014; Liu et al., 2010; Xiang, 2016), molecular genetics (Wang and Zhang, 2017; Lin et al., 2016), physiological ecology (Zhang et al., 2009; Jiao, 2016), cultivation (Du 2003; Li and Du, 2001; Du et al., 2016; Du et al., 2016) and so on. Its study areas are mainly concentrated in Henan, Hunan, Shaanxi, Guizhou and Sichuan. However, there are few reports on Eucommia ulmoides habitat, functional traits, medicinal component characteristics and relationships in between. In particular, Eucommia ulmoides, as an authentic medicinal material in Guizhou, has not been reported under the special karst ecological environment of Guizhou. In view of this, the genuine medicinal material Eucommia ulmoides produced in Guizhou is taken as the research object to study its habitat, functional traits and medicinal composition characteristics and explore the relationship in between in an attempt to explore the local characteristics of Eucommia ulmoides from Guizhou, and provide a theoretical basis for the cultivation of Eucommia ulmoides in Guizhou, cultivation of target medicinal components and comprehensive development and utilization of resources.

\section{Overview Of The Study Area And Methods}

\subsection{Overview of the study area}

Guizhou Province is located in the eastern part of the Yunnan-Guizhou Plateau, $103^{\circ} 36^{\prime} \sim 109^{\circ} 35^{\prime} \mathrm{E}, 24^{\circ} 37^{\prime} \sim 29^{\circ} 13^{\prime} \mathrm{N}$. The territory terrain is high in the west and low in the east, which inclines from the middle to the north, east and south, with an average elevation of 1,100 m. Dominated by plateau mountains, hills and basins, it has $92.5 \%$ of mountains and hills. There are many mountains in the territory, with one mountain stretching after another and presenting high mountains and deep valleys. There is Dalou Mountain in the north, slanting across the northern border from west to northeast; Miaoling Mountain spans the middle and south, with Wuling Mountain in the northeast, and towering Wumeng Mountain in the west. The highest altitude is $2900.6 \mathrm{~m}$, and the lowest altitude is $147.8 \mathrm{~m}$. Karst landforms have quite typical development, with exposed area of carbonate up to $109,084 \mathrm{~km}^{2}$, accounting for $61.9 \%$ of the total land 
area of the province (Wang,2003). On the typical karst landform development areas, the karst area has environmental degradation (Cai,1996), showing difficult soil formation, lack of lime-soil transition layer formed by carbonate rocks (Yang,1990), thin soil, discontinuous soil cover, and low ecological capacity (Li et al., 2016;). The climate is warm and humid, belonging to subtropical humid monsoon climate zone. The annual frost-free period is $250 \sim 300 \mathrm{~d}$. Warm in winter and cool in summer, it has average temperature of $3^{\circ} \mathrm{C} \varangle 6^{\circ} \mathrm{C}$ in the coldest month of January, which is higher compared to other areas at the same latitude. With average temperature of $22^{\circ} \mathrm{C} \sim 25^{\circ} \mathrm{C}$ in the hottest month of July, it is a typical area cool in summer. The annual precipitation is $1000 \sim 1400$ $\mathrm{mm}$, with obvious rainy season. At the same time, under the influence of atmospheric circulation and karst topography, Guizhou has formed a diversified microclimate characterized by "one mountain with four seasons, ten miles with different weathers", thus forming a characteristic and diverse habitat unique to Guizhou that produces genuine Chinese herbal medicines in special habitat. Where, woody genuine medicinal materials include fructus evodiae, gallnut and so on.

\subsection{Research methods}

\subsubsection{Main research ideas and overview of sample plots}

Based on the data from the fourth forest resource inventory of Guizhou Province, the distribution area of Eucommia ulmoides plantation was determined, and locations with a continuous distribution area of more than 3 mu of Eucommia ulmoides were selected for investigation. The survey factors include altitude, longitude, latitude, annual average rainfall, annual average temperature, annual extreme maximum temperature, annual extreme minimum temperature, average temperature in July, average temperature in January, annual average sunshine hours, planting years, provenance, forest type, soil lithology, soil type, landform type, slope, aspect, slope position, etc.

De-trend correspondence analysis (DCA) and redundancy analysis (RDA) were performed using Canoco for windows 4.5 software. 12 indexes of Eucommia ulmoides plantations at 90 distribution points in Guizhou Province, including altitude, longitude, latitude, annual average rainfall, annual average temperature, extreme maximum temperature, average temperature in July, average temperature in January, average annual sunshine hours, lithology, slope, and aspect were subjected to de-trend correspondence analysis (DCA) to obtain the gradient length of each ordination axis. The gradient lengths (LGA) of the four axes are $0.414,0.198,0.087,0.181$ in this study, which are all smaller than 3. Therefore, RDA analysis (Zhang,2004;Jan and Petr,2003) was adopted. Through RDA analysis, Eucommia ulmoides plantation in Guizhou Province can be divided into 4 types (Tab. 1, Fig. 1). That is, type A has low altitude, low, medium and high temperature rain slope latitude mixing, and short sunshine. Type B has medium altitude, low latitude and longitude, high temperature rain, positive oblique steep slope, medium sunshine. Type $\mathrm{C}$ has medium altitude, low latitude and longitude, moderate high temperature rain, gentle deflection steep slope in shady side and sunny side, medium sunshine. Type $D$ has high altitude, low longitude and latitude, low temperature and moderate rain, positive gentle slope, long sunshine. For the convenience of addressing, we use Type A, Type B, Type C, and Type D as substitute names (the same below). In this study, typical plots were selected from the above 4 types of Eucommia ulmoides plantations, with 3 replicates in each type, that is, 3 plots. Thus, there are a total of 12 plots for the 4 types, each with an area of $20 \mathrm{~m} \times 20 \mathrm{~m}$ (Zhang and Xu,2019). The specific conditions of the sample plots are shown in Tab. 1 .

Tab.1 General situation of four types of Eucommia ulmoides plantation plots 


\begin{tabular}{|c|c|c|c|c|c|c|c|}
\hline Type & $\begin{array}{l}\text { Slope and } \\
\text { elevation }\end{array}$ & $\begin{array}{l}\text { Slope } \\
\text { direction }\end{array}$ & $\begin{array}{l}\text { Longitude and } \\
\text { latitude }\end{array}$ & Vegetation characteristics & $\begin{array}{l}\text { Rock } \\
\text { exposure }\end{array}$ & Habitat & $\begin{array}{l}\text { Standard } \\
\text { sample } \\
\text { wood }\end{array}$ \\
\hline $\begin{array}{l}\text { A types: low altitude, } \\
\text { low temperature rain } \\
\text { slope latitude mixing, } \\
\text { short sunshine type }\end{array}$ & $26 \sim 35^{\circ}, 1100 \mathrm{~m}$ & $\begin{array}{l}\text { Semi } \\
\text { shady } \\
\text { slope }\end{array}$ & $\begin{array}{l}\text { E106.56589 } \\
\text { N27.65005 }\end{array}$ & $\begin{array}{l}12 \text { species of shrubs, } 1 \text { 3.0m high, } \\
\text { coverage } 20 \% \text {,There are Pyracantha } \\
\text { fortuneana, Coriaria nepalensis, } \\
\text { Rhamnus heterophylla, Myrsine } \\
\text { africana. etc. } 17 \text { species of grass, } \\
0.5 \sim 1.5 \mathrm{~m} \text { high, coverage } 40 \% \text {, There } \\
\text { are Imperata cylindrica, Arthraxon } \\
\text { hispidus, Aster trinervius } \\
\text { subsp.ageratoides, Odontosoria } \\
\text { chusana, Chrysanthemum indicum, } \\
\text { Miscanthus sinensis. etc. The ground } \\
\text { was covered with } 3 \sim 5 \mathrm{~cm} \text { litter. }\end{array}$ & $40.15 \%$ & $\begin{array}{l}\text { Soil } \\
\text { surface, } \\
\text { sand } \\
\text { shale, } \\
\text { downhill, } \\
\text { mid } \\
\text { subtropical } \\
\text { monsoon } \\
\text { humid } \\
\text { climate }\end{array}$ & $\begin{array}{l}\text { Hight } \rrbracket \\
9.6 \sim 14.0 \mathrm{~m} \rrbracket \\
\text { Breast- } \\
\text { height } \\
\text { Diameter } \rrbracket \\
8.4 \sim 12.0 \mathrm{~cm}\end{array}$ \\
\hline $\begin{array}{l}\text { B types: medium } \\
\text { altitude, low } \\
\text { longitude and } \\
\text { latitude, high } \\
\text { temperature rain, } \\
\text { positive oblique } \\
\text { steep slope, medium } \\
\text { sunshine type }\end{array}$ & $\begin{array}{l}16 \sim 25^{\circ} \rrbracket \\
1636 \mathrm{~m}\end{array}$ & $\begin{array}{l}\text { Semi } \\
\text { sunny } \\
\text { slope }\end{array}$ & $\begin{array}{l}\text { E104.81972 } \\
\text { N24.92222 } ه\end{array}$ & $\begin{array}{l}31 \text { species of shrubs, } 0.5 \sim 4.0 \mathrm{~m} \text { high, } \\
\text { coverage 50\%,There are } \\
\text { Hypericum monogynum, Litsea } \\
\text { cubeba, Rhamnus leptophylla, } \\
\text { Callerya nitida, Bauhinia glauca, } \\
\text { Pyracantha fortuneana, Itea } \\
\text { yunnanensis. etc. } 22 \text { species of grass, } \\
0.5 \sim 0.8 \mathrm{~m} \text { high, coverage } 65 \% \text {,There } \\
\text { are Arthraxon hispidus, Pteris vittata, } \\
\text { Artemisia annua, Carex montis- } \\
\text { everestii, Imperata cylindrica. etc. The } \\
\text { ground was covered with } 3 \sim 6 \mathrm{~cm} \\
\text { litter,and the ditch and pit were slightly } \\
\text { thick. }\end{array}$ & $74.35 \%$ & $\begin{array}{l}\text { Stone } \\
\text { groove, } \\
\text { stone } \\
\text { trough, soil } \\
\text { surface, } \\
\text { limestone, } \\
\text { middle } \\
\text { slope, } \\
\text { subtropical } \\
\text { monsoon } \\
\text { climate }\end{array}$ & $\begin{array}{l}\text { Hight } \rrbracket \\
3.0 \sim 15.0 \mathrm{~m} \rrbracket \\
\text { Breast- } \\
\text { height } \\
\text { Diameter } \rrbracket \\
6.8 \sim 8.5 \mathrm{~cm}\end{array}$ \\
\hline $\begin{array}{l}\text { C types: middle } \\
\text { altitude, low } \\
\text { longitude and } \\
\text { latitude, moderate } \\
\text { high temperature } \\
\text { rain, shady side and } \\
\text { sunny side have } \\
\text { gentle deflection } \\
\text { steep slope, medium } \\
\text { sunshine type }\end{array}$ & $\begin{array}{l}16 \sim 25^{\circ} \otimes \\
1240 \mathrm{~m}\end{array}$ & $\begin{array}{l}\text { Semi } \\
\text { sunny } \\
\text { slope }\end{array}$ & $\begin{array}{l}\text { E106.81833ㅁ } \\
\text { N26.46917 }\end{array}$ & $\begin{array}{l}18 \text { species of shrubs, 0.5 3.0m high, } \\
\text { coverage } 40 \% \text {,There are } \\
\text { Viburnum utile, Pyracantha } \\
\text { fortuneana, Rosa cymosa, Ligustrum } \\
\text { lucidum, Rhus chinensis, Quercus } \\
\text { fabri, Myrsine africana. etc. } \\
23 \text { species of grass, 0.5 2.0m high, } \\
\text { coverage 35\%,There are } \\
\text { Aster trinervius subsp.ageratoides, } \\
\text { Chrysanthemum indicum, Carex } \\
\text { montis-everestii, Imperata cylindrica, } \\
\text { Arthraxon hispidus, Odontosoria } \\
\text { chusana. etc., The ground was } \\
\text { covered with } 3 \sim 4 \mathrm{~cm} \text { litter. }\end{array}$ & $50.14 \%$ & $\begin{array}{l}\text { Soil } \\
\text { surface, } \\
\text { limestone, } \\
\text { middle } \\
\text { slope, } \\
\text { subtropical } \\
\text { humid } \\
\text { temperate } \\
\text { climate }\end{array}$ & $\begin{array}{l}\text { Hight } \rrbracket \\
7.1 \sim 12.1 \mathrm{~m} \rrbracket \\
\text { Breast- } \\
\text { height } \\
\text { Diameter } \rrbracket \\
5.1 \sim 24.2 \mathrm{~cm}\end{array}$ \\
\hline $\begin{array}{l}\text { D types: high } \\
\text { altitude, low } \\
\text { longitude and } \\
\text { latitude, low } \\
\text { temperature } \\
\text { moderate rain, } \\
\text { positive gentle slope, } \\
\text { long sunshine type }\end{array}$ & $\begin{array}{l}16 \sim 25^{\circ} \rrbracket \\
1770 \mathrm{~m}\end{array}$ & $\begin{array}{l}\text { Sunny } \\
\text { slope }\end{array}$ & $\begin{array}{l}\text { E104.82131 } \\
\text { N25.85414 }\end{array}$ & $\begin{array}{l}19 \text { species of shrubs, } 0.5 \sim 4.0 \mathrm{~m} \text { high, } \\
\text { coverage } 25 \% \text {,There are } \\
\text { Viburnum foetidum, Rhamnus } \\
\text { leptophylla, Pyracantha fortuneana, } \\
\text { Rhus chinensis, Ligustrum lucidum, } \\
\text { Hypericum monogynum, Stachyurus } \\
\text { obovatus, Aralia elata. etc. } 20 \text { species } \\
\text { of grass, } 0.4 \sim 1.5 \mathrm{~m} \text { high, coverage } \\
30 \%, \text { There are Imperata cylindrica, } \\
\text { Saccharum rufipilum, Cyperus } \\
\text { rotundus, Cyperus rotundus, } \\
\text { Parathelypteris glanduligera, } \\
\text { Oplismenus undulatifolius, } \\
\text { Woodwardia prolifera. etc. The } \\
\text { ground was covered with } 2 \sim 3 \mathrm{~cm} \\
\text { litter. }\end{array}$ & $55.24 \%$ & $\begin{array}{l}\text { Soil } \\
\text { surface, } \\
\text { limestone, } \\
\text { middle } \\
\text { slope, } \\
\text { subtropical } \\
\text { plateau } \\
\text { monsoon } \\
\text { climate } \\
\text { zone }\end{array}$ & $\begin{array}{l}\text { Hight } \rrbracket \\
7.1 \sim 12.1 \mathrm{~m} \rrbracket \\
\text { Breast- } \\
\text { height } \\
\text { Diameter } \rrbracket \\
8.2 \sim 11.7 \mathrm{~cm}\end{array}$ \\
\hline
\end{tabular}

Note: The seedlings of Eucommia ulmoides in the four sampling sites were all from the same batch of seedlings in Jiangjin District of Chongqing (formerly Jiangjin County of Sichuan Province) $₫$ which were planted in 1996.

\subsubsection{Sample collection and processing}

According to the average $\mathrm{DBH}$, tree height, crown width, under crown height and overall growth of Eucommia ulmoides in each plot, 3 plants with no disease and insect pests were selected from each plot, and a total of 36 samples in 12 plots were selected. The leaf samples of the tree samples were collected from the 3 positions of upper, middle, and bottom parts in the four directions of east, south, west, and north. A total of 12 leaf samples were collected from each sample tree, and 1 root bark sample and 1 trunk bark sample were collected from each sample tree. There are a total of 432 leaf samples, 36 root bark and 36 trunk bark samples in 12 plots. The samples were collected from May 29 to June 30, 2017. The trunk bark was sampled by girdling method at $130 \mathrm{~cm}$ from the ground. A second girding cut was made at $30 \mathrm{~cm}$ upwards with this as a starting point. Longitudinally cut a slit between the two girding cuts to peel off the trunk bark. The thick root bark was all dug out, removed with the soil attached to the thick roots to peel off the root bark. When sampling the soil, dig out all the roots of the sample tree and perform sampling in 3 layers of $0 \sim 10 \mathrm{~cm}, 10 \sim 20 \mathrm{~cm}$ and $>20 \mathrm{~cm}$ of the sample tree. Then, mix the 3 layers of soil samples, 
involving a total of 36 soil samples in 12 plots. Put each sample in a ziplock bag and record the sample name. The sample was taken back to the laboratory for drying after washing the soil attached to the root bark.

The leaf, trunk bark and root bark samples were respectively placed in an oven at $80^{\circ} \mathrm{C}$ to be dried to constant weight and crushed, and screened through an 80-mesh standard nylon sieve. The sieved samples were put into a ziplock bag, with name recorded. The soil was naturally air-dried, ground in a mortar, and stored in a ziplock bag after screened through 80 mesh and 20 mesh nylon sieves for later use. 10 fine roots that are clean and intact with a diameter of $\leq 2$ $\mathrm{mm}$ were selected and dried at $70^{\circ} \mathrm{C}$ after measurement of root length and root volume. After dry weight was calculated, the roots were crushed and screened through an 80-mesh sieve for later use, mainly to measure the content of root carbon, nitrogen, and phosphorus.

\subsubsection{Determination of medicinal components in root bark, trunk bark and leaf of Eucommia ulmoides}

The content of medicinal components was determined by high performance liquid chromatography. Accurately weigh aucubin $3.7 \mathrm{mg}$, genipinic acid $1.2 \mathrm{mg}$, geniposide $0.9 \mathrm{mg}$, chlorogenic acid $1 \mathrm{mg}$ and dilute to $10 \mathrm{~mL}$ with methanol to obtain single standard solution with $0.37 \mathrm{mg} / \mathrm{mL}$ aucubin, $0.12 \mathrm{mg} / \mathrm{mL}$ genipinic acid, $0.09 \mathrm{mg} / \mathrm{mL}$ geniposide, $0.10 \mathrm{mg} / \mathrm{mL}$ chlorogenic acid. Separately draw $250 \mathrm{uL}$ aucubin, $300 \mathrm{uL}$ genipinic acid, $400 \mathrm{uL}$ geniposide, and $200 \mathrm{uL}$ chlorogenic acid from the solution to obtain mixed standard solution containing $0.082 \mathrm{mg} / \mathrm{mL}$ aucubin and $0.032 \mathrm{mg} / \mathrm{mL}$ genipinic acid, $0.032 \mathrm{mg} / \mathrm{mL}$ geniposide and $0.018 \mathrm{mg} / \mathrm{mL}$ chlorogenic acid.

Weigh $1.0000 \mathrm{~g}$ of dried root bark, trunk bark and sample leaf of Eucommia ulmoides respectively, put them in a $250 \mathrm{~mL}$ Erlenmeyer flask, add $50 \mathrm{~mL} 70 \%$ methanol, perform ultrasonic $\left(30^{\circ} \mathrm{C}, 300 \mathrm{~W}, 40 \mathrm{~Hz}\right)$ extraction for $30 \mathrm{~min}$, transfer the solution to a $100 \mathrm{~mL}$ centrifuge tube, centrifuge $(4000 \mathrm{r} / \mathrm{min})$ for $60 \mathrm{~min}$, filter and dilute to $50 \mathrm{~mL}$, shake well, pass through a $0.45 \mu \mathrm{m}$ microporous membrane, take the filtrate, transfer it to a $2.5 \mathrm{~mL}$ sample bottle to obtain the test solution. The chromatographic column was a ZORBAX Eclipse Plus C18 column $\left(4.6 \times 250 \mathrm{~mm}, 5 \mu \mathrm{m}\right.$; Agilent); the column temperature was $30^{\circ} \mathrm{C}$; the mobile phase was acetonitrile (A)-0.1\% phosphoric acid aqueous solution (B) (97:3); the injection volume was $5 \mu \mathrm{L}$; volume flow rate was $1.0 \mathrm{~mL} / \mathrm{min}$; detection wavelength of genipinic acid, chlorogenic acid, and geniposide $\lambda=235 \mathrm{~nm}$, detection wavelength of aucubin $\lambda=208$. Qualitative analysis was made according to the peak retention time of the reference substance, and content of different medicinal components was calculated according to the peak area.

\subsubsection{Soil physical and chemical properties and determination of soil and fine root, root bark, trunk bark and leaf elements of Eucommia ulmoides}

The soil moisture content was determined by gravimetric method, the soil bulk density was determined by cutting ring method, the soil organic matter was determined by the potassium dichromate external heating method, the soil total nitrogen was determined by the semi-micro Kelvin method, the alkalihydrolyzable nitrogen was determined by alkaline hydrolysis diffusion method. Soil total phosphorus was determined by $\mathrm{HClO}_{4}-\mathrm{H}_{2} \mathrm{SO}_{4}$ digestion- $\mathrm{Mo}_{-} \mathrm{Sb}$ colorimetric method, rapidly available phosphorus was determined by $0.5 \mathrm{~mol} / \mathrm{L} \mathrm{NaHCO}{ }_{3}$ extraction-colorimetric method, soil total potassium was determined by $\mathrm{NaOH}$ melting-flame photometry, and rapidly available potassium was determined by $\mathrm{NH}_{4} \mathrm{OAc}$ extraction-flame photometry, soil pH value was determined by $\mathrm{pH}$ meter. The content of metal elements in soil, root bark, trunk bark and leaves was determined by nitric acid-perchloric acid digestion-flame photometry. The total carbon content of fine roots and leaf total carbon content were determined by potassium dichromate external heating method. The total nitrogen content of fine roots and leaf total nitrogen content were determined by $\mathrm{H}_{2} \mathrm{SO}_{4}-\mathrm{H}_{2} \mathrm{O}_{2}$ digestion-Nessler's colorimetric method. The total phosphorus content of fine roots and leaf total phosphorus content were determined by $\mathrm{H}_{2} \mathrm{SO}_{4}-\mathrm{H}_{2} \mathrm{O}_{2}$ digestion-vanadium molybdate yellow colorimetric method. The total potassium content of fine roots and leaf total potassium content were determined by $\mathrm{H}_{2} \mathrm{SO}_{4}-\mathrm{H}_{2} \mathrm{O}_{2}$ digestion-flame atomic absorption spectrometry (Bao,1999). The chlorophyll fluorescence parameter Fv/Fm was determined by a chlorophyll fluorometer (MINI-PAM-囚, Walz, Germany).

\subsubsection{Data Statistics and Analysis}

SPSS 22.0 and Excel software were used for data statistical analysis, and Canoco for windows4.5 software was used for redundancy analysis (RDA). The analysis of variance was made using LSD multiple comparison ( $a=0.05$ ), and Pearson was used for correlation analysis ( $a=0.05)$.

\section{Results And Analysis}

\subsection{Types of Eucommia ulmoides plantations in Guizhou}

Fig. 1 shows: The 90 distribution points can be divided into 4 types. Based on 12 indexes of clustering (i.e. altitude, longitude, latitude, annual average rainfall, annual average temperature, extreme maximum temperature, average temperature of January, average temperature of July, annual average sunshine hours, lithology, slope, aspect), these four types can be named as follows: Type A has low altitude, low, medium and high temperature rain slope latitude mixing, and short sunshine. Type B has medium altitude, low latitude and longitude, high temperature rain, positive oblique steep slope, medium sunshine. Type $C$ has medium altitude, low latitude and longitude, moderate high temperature rain, gentle deflection steep slope in shady side and sunny side, medium sunshine. Type $D$ has high altitude, low longitude and latitude, low temperature and moderate rain, positive gentle slope, long sunshine. Where, the factors with a greater impact on the type of Eucommia ulmoides plantation include altitude, longitude, latitude, and annual average sunshine hours. The less influential factors are average temperature of July, extreme maximum temperature, slope, aspect and lithology.For distribution area of the 4 types of Eucommia ulmoides forests (Fig. 2), there are 40 distribution points for type A, 12 for type B, 31 for type C, and 7 for type D, mainly concentrated in northern Guizhou-central Guizhouwestern Guizhou and southwestern Guizhou. Type A is mainly distributed in northern and southern Guizhou, type C is mainly distributed in central and western Guizhou, while type B and D are mainly distributed in smaller areas in southwestern Guizhou.

\subsection{Habitat characteristics of different types of Eucommia ulmoides plantations}

Fig. 3 shows: In general, organic matter, total $\mathrm{P}$, rapidly available $\mathrm{P}$, total $\mathrm{N}$, alkali-hydrolyzable $\mathrm{N}$, pH value, soil moisture, Mn, and $\mathrm{Zn}$ content are the highest in type $\mathrm{B}$, and these habitat indexes are basically the lowest in type $\mathrm{A}$; $\mathrm{Ca}$ content is the highest in Type A, higher in type $\mathrm{B}$, lower in type $\mathrm{C}$, and the lowest in type 
D. Fe content and rapidly available potassium in various types show opposite trend compared to Ca content. The total $\mathrm{K}$ and soil bulk density are the highest in type A, followed by type $D$ and Type $C$, with the lowest content in type B. The above indicates that different types of Eucommia ulmoides plantations have different habitat quality, but in general, Type B is intensity karst rocky desertification habitat, and Type A is potential karst rocky desertification habitat. Type C, $D$ is in the middle, and the difference is significant.

\subsection{Species diversity of the shrub-grass layer of the community}

The survey found that the average DBH of Eucommia ulmoides in type A sample plot $\left(400 \mathrm{~m}^{2}\right)$ was $9.19 \mathrm{~cm}$, with an average of 87 plants; the average DBH of Eucommia ulmoides in type B sample plot was $6.86 \mathrm{~cm}$, with an average of 48 plants; the average DBH of Eucommia ulmoides in type $\mathrm{C}$ sample plot was $11.15 \mathrm{~cm}$, with an average of 38 plants; the average DBH of Eucommia ulmoides in type D sample plot was $8.81 \mathrm{~cm}$, with an average of 152 plants. The species diversity of shrub-grass layer under forest (Fig. 4) shows that: the Margalef index of the shrub-grass layer community of Eucommia ulmoides plantation is the highest in type $B$, followed by type $C$, with the smallest index in type A. The difference between type $A$ and type $B$ is extremely significant, with significant difference between type $A$ and type $C$ and between type $B$ and type $D$. Shannon index and Simpson index both show a descending order in type $D$, type B, type $C$, and type A. The shrub-grass layers of the 4 Eucommia ulmoides plantations show no significant difference between the two indexes. The uniformity index shows a descending order in type $D$, type $C$, type $A$, and type $B$, only with significant difference between type $B$ and type $D$. The above analysis shows that, as a whole, the species diversity of the shrub-grass layer is higher in type $D$ and type $B$, followed by type $A$ and $C$. This may be due to the fact that type $B$ and type $D$ have smaller $D B H$ and crown width compared to type $A$ and type $C$, which renders sufficient sunshine under type $B$ and type $C$ Eucommia ulmoides plantations and facilitates the growth of shrubs and grass.

\subsection{Functional traits of different types of Eucommia ulmoides plantations}

Fig. 5 shows: among the plant functional traits of the four types of Eucommia ulmoides plantations, the root carbon content, root nitrogen content, petiole length, specific leaf area, leaf nitrogen content, leaf phosphorus content, leaf potassium content, and crown length ratio are all the highest in type $C$, while the root carbon content, root nitrogen content, specific leaf area, crown length ratio, branch and leaf index are the lowest in type A, with moderate index in type $B$ and type D. Petiole length is the shortest in type B, leaf nitrogen content, leaf phosphorus content, leaf potassium content are the lowest in type B. Type A has the highest root carbon nitrogen ratio and chlorophyll fluorescence parameters, followed by type $D$, and there is little difference between type $B$ and type $C$. Root potassium content, leaf dry weight, leaf carbon content, bark $\mathrm{DBH}$ ratio are the highest in type $\mathrm{D}$, while type $\mathrm{A}$ and $\mathrm{C}$ have the lowest bark $\mathrm{DBH}$ ratio, and type $\mathrm{C}$ has the lowest leaf dry weight and leaf carbon content. Root phosphorus content is the highest in type $\mathrm{B}$, higher in type $\mathrm{C}$, lower in type $\mathrm{A}$ and the lowest in type $D$. Type $B$ and type $C$ equally have the highest branch and leaf index, followed by type $D$, and type $A$ ranks the lowest. Except the insignificant differences in root carbon content and leaf nitrogen content in the four types of Eucommia ulmoides plantations, other indexes of plant functional traits have significant or extremely significant differences between the four types of $A, B, C$, and D. The above suggests that type A Eucommia ulmoides has the best growth, followed by type $\mathrm{C}$, while type $\mathrm{B}$ and $\mathrm{D}$ grow poorly.

\subsection{Content characteristics of medicinal components in root bark, trunk bark and leaves}

Fig. 6 shows: the content of genipinic acid is the highest in root bark, followed by trunk bark, with the lowest content in leaves. Root bark and trunk bark have the highest content in type $D$, followed by type $C$ and type $A$, with the lowest content in type $B$. The leaf content is higher in type B and $D$ and lower in type $A$ and $C$. The content of chlorogenic acid is the highest in leaf, followed by trunk bark, with the lowest content in root bark. Root bark and trunk bark have the highest content in type $A$ and $C$, followed by type $B$, with the lowest content in type $D$. Leaf content is the highest in type $B$, followed by type $C$ and type $D$, with the lowest content in type A. Geniposide has the highest content in trunk bark, lower content in root bark and leaf. Root bark content is higher in type A and D and lower in type $A$ and $C$. Leaf content is higher in type $B$ and $C$ and lower in type A and D. Trunk bark content is the highest in type $D$, followed by type $C$, with lower content in type A and B. Aucubin has the highest content in root bark, followed by trunk bark, with the lowest content in leaves. Root bark, trunk bark, and leaves have higher content in type A and D and lower content in type B and C. The above suggests that the different parts and habitats of Eucommia ulmoides lead to different content of medicinal components.

\subsection{Element enrichment coefficients of root bark, trunk bark and leaves in different types of Eucommia ulmoides}

Tab. 2 shows: Type B has the highest enrichment coefficient of $\mathrm{K}$ element in root bark, trunk bark, and leaf, followed by type $\mathrm{C}$, with the smallest coefficient in type $A$ and $D$. Leaf has the highest enrichment coefficients among the four forest types in overall, followed by root bark, while trunk bark has the smallest coefficient. Ca element enrichment coefficient in root bark, trunk bark, and leaf is the highest in type $D$, followed by type $C$, with the smallest coefficient in types $A$ and $B$. Type $D$ has significantly higher coefficient compared to the other three types. Trunk bark has the highest enrichment coefficient among the 4 forest types on the whole. Type A has the highest enrichment coefficients of Fe and Mn elements in root bark, trunk bark and leaf, followed by other types, and the overall difference is insignificant. In terms of parts of Eucommia ulmoides, enrichment coefficient of Fe element is the highest in root bark, with smaller coefficient in trunk bark and leaf. Enrichment coefficient of $\mathrm{Mn}$ element is the highest in leaves as a whole, and little difference is shown between root bark and trunk bark. Type A has the highest enrichment coefficient of Zn element in root bark, trunk bark and leaves, followed by type $C$ and $D$, with the smallest coefficient in type B. Enrichment coefficient of Zn element is the highest in trunk bark, with insignificant difference between root bark and leaf. The above suggests that in terms of the same element, for different parts of Eucommia ulmoides in different forest types, element enrichment coefficient exhibits consistent change law, which reflects the consistency of physiological and ecological activities of Eucommia ulmoides in different forest types. However, in terms of different elements, each part of Eucommia ulmoides exhibits inconsistent change law in element enrichment coefficient in different forest types, reflecting complexity in physiological and ecological activities of Eucommia ulmoides.

Tab. 2 Enrichment coefficient of various elements in soil from various medicinal parts of Eucommia ulmoides 


\begin{tabular}{|lllllll|}
\hline Medicinal sites & Type & $\mathrm{K}$ & $\mathrm{Ca}$ & $\mathrm{Fe}$ & $\mathrm{Mn}$ & $\mathrm{Zn}$ \\
\hline Root bark & Type A & $0.1766 \pm 0.0731 \mathrm{a}$ & $0.7938 \pm 0.3361 \mathrm{a}$ & $0.0199 \pm 0.0158 \mathrm{a}$ & $0.3423 \pm 0.4171 \mathrm{ab}$ & $0.2453 \pm 0.0923 \mathrm{ag}$ \\
\hline & Type B & $0.5205 \pm 0.146 \mathrm{bef}$ & $1.1014 \pm 0.2554 \mathrm{a}$ & $0.0085 \pm 0.0007 \mathrm{~b}$ & $0.0287 \pm 0.0067 \mathrm{a}$ & $0.0592 \pm 0.0158 \mathrm{bce}$ \\
\hline & Type C & $0.3008 \pm 0.0521 \mathrm{ad}$ & $2.0382 \pm 0.3349 \mathrm{a}$ & $0.0065 \pm 0.0011 \mathrm{~b}$ & $0.0818 \pm 0.0312 \mathrm{a}$ & $0.1386 \pm 0.0378 \mathrm{acfh}$ \\
\hline & Type D & $0.1885 \pm 0.0047 \mathrm{a}$ & $7.8813 \pm 6.4334 \mathrm{ac}$ & $0.0066 \pm 0.0012 \mathrm{~b}$ & $0.0712 \pm 0.0208 \mathrm{a}$ & $0.1632 \pm 0.0871 \mathrm{acij}$ \\
\hline Trunk bark & Type A & $0.1602 \pm 0.0795 \mathrm{a}$ & $1.3844 \pm 0.5781 \mathrm{a}$ & $0.0056 \pm 0.0017 \mathrm{~b}$ & $0.2905 \pm 0.3156 \mathrm{ac}$ & $0.7053 \pm 0.1247 \mathrm{~d}$ \\
\hline & Type B & $0.3575 \pm 0.0609 \mathrm{bd}$ & $1.287 \pm 0.1288 \mathrm{a}$ & $0.0008 \pm 0.0000 \mathrm{~b}$ & $0.0161 \pm 0.003 \mathrm{a}$ & $0.0472 \pm 0.0037 \mathrm{bfikl}$ \\
\hline & Type C & $0.1729 \pm 0.0453 \mathrm{a}$ & $2.6043 \pm 0.6116 \mathrm{ad}$ & $0.0011 \pm 0.0006 \mathrm{~b}$ & $0.0983 \pm 0.0463 \mathrm{a}$ & $0.1195 \pm 0.0324 \mathrm{aekm}$ \\
\hline leaves & Type D & $0.1442 \pm 0.0176 \mathrm{a}$ & $12.5545 \pm 10.9966 \mathrm{bc}$ & $0.0013 \pm 0.0005 \mathrm{~b}$ & $0.0781 \pm 0.0293 \mathrm{a}$ & $0.2273 \pm 0.1278 \mathrm{an}$ \\
\hline & Type A & $0.3887 \pm 0.1819 \mathrm{bd}$ & $1.0219 \pm 0.3656 \mathrm{a}$ & $0.0033 \pm 0.0009 \mathrm{~b}$ & $0.8757 \pm 1.3055 \mathrm{bc}$ & $0.314 \pm 0.1117 \mathrm{gn}$ \\
\hline & Type B & $1.1488 \pm 0.1213 \mathrm{c}$ & $0.9123 \pm 0.0729 \mathrm{a}$ & $0.002 \pm 0.0008 \mathrm{~b}$ & $0.0251 \pm 0.0038 \mathrm{a}$ & $0.039 \pm 0.0044 \mathrm{bhjmo}$ \\
\hline & Type C & $0.59 \pm 0.1715 \mathrm{fg}$ & $2.7393 \pm 0.5734 \mathrm{ae}$ & $0.0007 \pm 0.0003 \mathrm{~b}$ & $0.1233 \pm 0.0679 \mathrm{a}$ & $0.1657 \pm 0.0081 \mathrm{aelo}$ \\
\hline & Type D & $0.4493 \pm 0.0364 \mathrm{bdg}$ & $9.6841 \pm 7.1993 \mathrm{bcde}$ & $0.0008 \pm 0.0004 \mathrm{~b}$ & $0.137 \pm 0.0466 \mathrm{a}$ & $0.1481 \pm 0.0945 \mathrm{aelo}$ \\
\hline
\end{tabular}

Note: The same letters in the same column in the table indicate no significant difference, different letters indicate significant or very significant difference.

\subsection{Correlation among the species diversity, functional traits and medicinal ingredient content of the shrub-grass layer in habitats and communities}

\subsubsection{Correlation between functional traits and habitat}

Tab. 3 shows: as a whole, in terms of functional traits, petiole length, leaf phosphorus content, root nitrogen content, root carbon nitrogen ratio, branch and leaf index are in good correlation with habitat; followed by leaf dry weight, chlorophyll fluorescence parameters, leaf carbon content, root phosphorus content, crown length ratio, while specific leaf area, leaf nitrogen content, root carbon content, and bark DBH ratio have poor correlation, indicating differences in the impact of habitat on the functional traits of Eucommia ulmoides. Where, petiole length, leaf phosphorus content, root nitrogen content, root carbon nitrogen ratio, branch and leaf index exert the biggest influence. Seen from habitat, rapidly available phosphorus, total potassium, pH value, soil bulk density and functional traits exhibit good correlation, with significant correlations shown between petiole length and total potassium, organic matter, total phosphorus, total nitrogen, alkali-hydrolyzable nitrogen, rapidly available phosphorus, and soil moisture; between leaf phosphorus content and total potassium, organic matter, total nitrogen, and alkali-hydrolyzable nitrogen; between root nitrogen content and rapidly available potassium, rapidly available phosphorus, soil bulk density; between root carbon nitrogen ratio and soil bulk density, total potassium, total phosphorus, rapidly available phosphorus, and pH; between branch and leaf index and soil moisture, total phosphorus, rapidly available phosphorus, soil bulk density. The above suggests that soil potassium, phosphorus, pH, and bulk density have a big impact on the functional traits of Eucommia ulmoides, especially in soil pH value and bulk density. This reflects the commonality that soil habitat $\mathrm{pH}$ value and bulk density affect plant growth in karst areas.

Tab.3 Correlation between functional traits and habitat of Eucommia ulmoides 


\begin{tabular}{|c|c|c|c|c|c|c|c|c|c|c|}
\hline & $\begin{array}{l}\text { Organic } \\
\text { matter }\end{array}$ & $\begin{array}{l}\text { Total } \\
\text { phosphorus }\end{array}$ & $\begin{array}{l}\text { Rapidly } \\
\text { phosphorus }\end{array}$ & $\begin{array}{l}\text { Total } \\
\text { nitrogen }\end{array}$ & $\begin{array}{l}\text { Alkali- } \\
\text { hydrolyzable } \\
\text { nitrogen }\end{array}$ & $\begin{array}{l}\text { Total } \\
\text { potassium }\end{array}$ & $\begin{array}{l}\text { Available } \\
\text { potassium }\end{array}$ & $\begin{array}{l}\mathrm{pH} \\
\text { value }\end{array}$ & $\begin{array}{l}\text { Soil } \\
\text { bulk } \\
\text { density }\end{array}$ & $\begin{array}{l}\text { Soil } \\
\text { moisture }\end{array}$ \\
\hline Petiole length & $-0.778^{* \star}$ & $-0.784^{\star \star}$ & $-0.647^{*}$ & $-0.885^{\star \star}$ & $-0.795^{\star \star}$ & $0.603^{*}$ & 0.199 & -0.531 & 0.441 & $-0.649^{*}$ \\
\hline Leaf dry weight & -0.118 & -0.478 & -0.274 & -0.286 & -0.192 & 0.099 & 0.039 & $-0.837^{\star *}$ & 0.411 & -0.257 \\
\hline Specific leaf area & -0.096 & 0.420 & 0.396 & 0.003 & 0.139 & -0.014 & 0.431 & 0.410 & -0.486 & 0.095 \\
\hline $\begin{array}{l}\text { Chlorophy } \\
\text { fluorescence } \\
\text { parameters }\end{array}$ & -0.399 & -0.535 & -0.544 & -0.441 & -0.396 & 0.315 & -0.267 & $-0.638^{*}$ & $0.628^{*}$ & -0.564 \\
\hline $\begin{array}{l}\text { Leaf carbon } \\
\text { content }\end{array}$ & -0.108 & -0.483 & -0.401 & -0.362 & -0.236 & 0.276 & -0.066 & $-0.679^{*}$ & 0.566 & -0.307 \\
\hline $\begin{array}{l}\text { Leaf nitrogen } \\
\text { content }\end{array}$ & -0.373 & -0.175 & -0.260 & -0.361 & -0.404 & 0.406 & 0.283 & 0.237 & 0.019 & -0.28 \\
\hline $\begin{array}{l}\text { Leaf phosphorus } \\
\text { content }\end{array}$ & $-0.800^{\star *}$ & -0.433 & -0.520 & $-0.591^{*}$ & $-0.630^{*}$ & $0.681^{*}$ & -0.165 & -0.131 & 0.233 & -0.536 \\
\hline $\begin{array}{l}\text { Root carbon } \\
\text { content }\end{array}$ & -0.314 & 0.070 & 0.144 & -0.118 & 0.014 & 0.114 & -0.105 & -0.089 & -0.259 & -0.018 \\
\hline $\begin{array}{l}\text { Root nitrogen } \\
\text { content }\end{array}$ & 0.385 & 0.502 & $0.580^{*}$ & 0.339 & 0.326 & -0.537 & $0.767^{* *}$ & 0.395 & $-0.756^{* *}$ & 0.473 \\
\hline $\begin{array}{l}\text { Root phosphorus } \\
\text { content }\end{array}$ & 0.520 & 0.143 & 0.360 & 0.372 & 0.268 & $-0.690^{*}$ & 0.329 & 0.090 & -0.322 & 0.409 \\
\hline $\begin{array}{l}\text { Root carbon- } \\
\text { nitrogen ratio }\end{array}$ & -0.360 & $-0.616^{*}$ & $-0.632^{*}$ & -0.468 & -0.423 & $0.740^{\star *}$ & -0.430 & $-0.587^{*}$ & $0.755^{* *}$ & -0.467 \\
\hline $\begin{array}{l}\text { DBH Ratio of } \\
\text { Bark }\end{array}$ & 0.548 & 0.158 & 0.338 & 0.341 & 0.379 & -0.174 & 0.422 & -0.281 & -0.290 & 0.432 \\
\hline $\begin{array}{l}\text { Crown length } \\
\text { ratio }\end{array}$ & -0.132 & 0.383 & 0.311 & 0.033 & 0.039 & -0.171 & 0.426 & 0.551 & $-0.666^{*}$ & 0.217 \\
\hline $\begin{array}{l}\text { Branch and leaf } \\
\text { index }\end{array}$ & 0.309 & $0.607^{\star}$ & $0.644^{\star}$ & 0.381 & 0.404 & -0.364 & 0.286 & 0.334 & $-0.831^{\star *}$ & 0.714 ** \\
\hline
\end{tabular}

Note: $n=12$, * represents $p<0.05$, ** represent $p<0.01$

\subsubsection{Correlation between the content of medicinal components and the species diversity of the shrub-grass layer of the community}

Tab. 4 shows: in Eucommia ulmoides plantation, on the whole, root bark geniposide content, root bark aucubin content, trunk bark aucubin content, leaf chlorogenic acid content, leaf aucubin content show a significant relationship with species diversity of shrub-grass layer in the community, while the others fail to reach a significant relationship, but certain correlation is shown. Where, the root bark geniposide content, leaf chlorogenic acid content, root bark, trunk bark and leaf aucubin content display a good correlation with number of species, Margalef index, Shannon index, evenness index of shrub-grass layer of the community. It suggests that except root bark chlorogenic acid, the content of medicinal components in the root bark, trunk bark and leaves of Eucommia ulmoides is subject to influence of species diversity of shrub-grass layer in the community. In particular, greater influence is exerted on aucubin content in root bark, trunk bark and leaves of Eucommia ulmoides.

Tab. 4 Correlation between the contents of medicinal components in root bark, trunk bark and leaves and species diversity in community shrub layer

\begin{tabular}{|c|c|c|c|c|c|c|c|c|c|c|}
\hline & $\begin{array}{l}\text { Root } \\
\text { bark } \\
\text { Genipinic } \\
\text { acid }\end{array}$ & $\begin{array}{l}\text { Root bark } \\
\text { Chlorogenic } \\
\text { acid }\end{array}$ & $\begin{array}{l}\text { Root bark } \\
\text { geniposide }\end{array}$ & $\begin{array}{l}\text { Root } \\
\text { bark } \\
\text { aucubin }\end{array}$ & $\begin{array}{l}\text { Trunk bark } \\
\text { Genipinic acid }\end{array}$ & $\begin{array}{l}\text { Trunk bark } \\
\text { Chlorogenic } \\
\text { acid }\end{array}$ & $\begin{array}{l}\text { Trunk bark } \\
\text { geniposide }\end{array}$ & $\begin{array}{l}\text { Trunk } \\
\text { bark } \\
\text { aucubin }\end{array}$ & $\begin{array}{l}\text { Leaves } \\
\text { Genipinic acid }\end{array}$ & $\begin{array}{l}\text { Leaves } \\
\text { chlorogenic } \\
\text { acid }\end{array}$ \\
\hline $\begin{array}{l}\text { Number } \\
\text { of } \\
\text { species }\end{array}$ & -0.398 & 0.059 & $-0.759^{\star \star}$ & $-0.804^{\star} \star$ & -0.307 & -0.167 & -0.137 & $-0.726^{\star \star}$ & 0.182 & $0.801^{\star \star}$ \\
\hline $\begin{array}{l}\text { Margalef } \\
\text { index }\end{array}$ & -0.369 & 0.014 & $-0.854^{\star \star}$ & $-0.839^{\star} \star$ & -0.274 & -0.253 & -0.127 & $-0.802^{\star *}$ & 0.175 & $0.867^{\star \star}$ \\
\hline $\begin{array}{l}\text { Shannon } \\
\text { index }\end{array}$ & 0.499 & 0.104 & $0.665^{*}$ & $0.589^{*}$ & 0.456 & 0.246 & 0.456 & $0.596^{*}$ & -0.233 & $-0.675^{*}$ \\
\hline $\begin{array}{l}\text { Simpson } \\
\text { Index }\end{array}$ & -0.075 & -0.098 & 0.127 & 0.225 & -0.019 & -0.204 & -0.090 & 0.213 & -0.18 & -0.108 \\
\hline
\end{tabular}


Tab. 5 shows: on the whole, the contents of medicinal components in Eucommia root bark, trunk bark and leaves show good correlation with soil total phosphorus, rapidly available phosphorus, soil bulk density, soil moisture, soil Mn, total nitrogen, alkali-hydrolyzable nitrogen, pH value, and soil Zn, followed by the correlation with soil Fe, soil $\mathrm{Ca}$, and organic matter. There is poor correlation with total potassium and rapidly available potassium. Where, significant correlation is exhibited between the content of leaf chlorogenic acid and organic matter, total phosphorus, rapidly available phosphorus, total nitrogen, alkalihydrolyzable nitrogen, soil moisture, soil Mn content, soil Zn content, soil bulk density, soil total potassium; between trunk bark aucubin content and soil bulk density, total phosphorus, rapidly available phosphorus, total nitrogen, alkali-hydrolyzable nitrogen, pH value, soil moisture, soil Mn content, soil Zn content; between root bark geniposide content and soil bulk density, total phosphorus, rapidly available phosphorus, soil Mn content, total nitrogen, alkali-hydrolyzable nitrogen, soil moisture, soil Zn content; between root bark aucubin content and soil bulk density, total phosphorus, rapidly available phosphorus, total nitrogen, $\mathrm{pH}$ value, soil moisture, soil Mn content; between trunk bark genipinic acid content and soil Fe, total nitrogen, alkali-hydrolyzable nitrogen, soil Mn content, soil Zn content; between leaf aucubin content and soil bulk density, total phosphorus, rapidly available phosphorus, pH value, etc. The above suggests that soil physical and chemical indexes in Eucommia ulmoides habitat and the content of metal elements exert varying degrees of influence on the content of medicinal components in root bark, trunk bark and leaves of Eucommia ulmoides. In particular, leaf chlorogenic acid, trunk bark aucubin, root bark geniposide, root bark aucubin, trunk bark genipinic acid are greatly affected by the above-mentioned soil physical and chemical indexes and content of metal elements.

Tab. 5 Relationships between contents of medicinal components in root bark, trunk bark and leaves and habitat

\begin{tabular}{|c|c|c|c|c|c|c|c|c|c|c|c|}
\hline & $\begin{array}{l}\text { Total } \\
\text { phosphorus }\end{array}$ & $\begin{array}{l}\text { Rapidly } \\
\text { phosphorus }\end{array}$ & $\begin{array}{l}\text { Total } \\
\text { nitrogen }\end{array}$ & $\begin{array}{l}\text { Alkaline } \\
\text { Hydrolysis } \\
\text { nitrogen }\end{array}$ & $\begin{array}{l}\text { Total } \\
\text { potassium }\end{array}$ & $\begin{array}{l}\text { Available } \\
\text { potassium }\end{array}$ & $\begin{array}{l}\mathrm{pH} \\
\text { value }\end{array}$ & $\begin{array}{l}\text { Volume } \\
\text { weight } \\
\text { of soil }\end{array}$ & $\begin{array}{l}\text { Soil } \\
\text { moisture }\end{array}$ & Soil Ca & Soil Fe \\
\hline $\begin{array}{l}\text { Root bark } \\
\text { Genipinic acid }\end{array}$ & -0.462 & -0.198 & -0.446 & -0.351 & 0.147 & 0.534 & $-0.681^{*}$ & 0.054 & -0.034 & $-0.732^{\star *}$ & $0.685^{\star}$ \\
\hline $\begin{array}{l}\text { Root bark } \\
\text { Chlorogenic } \\
\text { acid }\end{array}$ & 0.119 & -0.146 & -0.157 & -0.137 & 0.021 & -0.422 & 0.436 & 0.122 & -0.410 & 0.537 & -0.428 \\
\hline $\begin{array}{l}\text { Root bark } \\
\text { geniposide }\end{array}$ & $-0.796^{\star \star}$ & $-0.824^{\star \star}$ & $-0.691^{*}$ & $-0.679^{*}$ & 0.500 & -0.227 & -0.497 & $0.884^{\star \star}$ & $-0.705^{*}$ & 0.125 & -0.088 \\
\hline $\begin{array}{l}\text { Root bark } \\
\text { aucubin }\end{array}$ & $-0.658^{*}$ & $-0.655^{*}$ & $-0.587^{*}$ & -0.494 & 0.450 & -0.015 & $-0.729^{\star *}$ & $0.748^{* *}$ & $-0.576^{*}$ & -0.203 & 0.039 \\
\hline $\begin{array}{l}\text { Trunk bark } \\
\text { Genipinic acid }\end{array}$ & -0.572 & -0.411 & $-0.668^{*}$ & $-0.631^{*}$ & 0.429 & 0.352 & -0.345 & 0.148 & -0.169 & -0.557 & $0.598^{*}$ \\
\hline $\begin{array}{l}\text { Trunk bark } \\
\text { Chlorogenic } \\
\text { acid }\end{array}$ & -0.066 & -0.272 & -0.258 & -0.264 & 0.092 & 0.008 & 0.452 & 0.121 & -0.466 & 0.482 & -0.348 \\
\hline $\begin{array}{l}\text { Trunk bark } \\
\text { geniposide }\end{array}$ & -0.311 & -0.089 & -0.312 & -0.280 & 0.102 & 0.512 & -0.506 & -0.063 & 0.097 & $-0.729^{* \star}$ & $0.834^{* *}$ \\
\hline $\begin{array}{l}\text { Trunk bark } \\
\text { aucubin }\end{array}$ & $-0.788^{\star *}$ & $-0.771^{\star *}$ & $-0.608^{*}$ & $-0.591^{*}$ & 0.381 & -0.357 & $-0.684^{*}$ & $0.895^{\star \star}$ & $-0.662^{\star}$ & 0.115 & -0.176 \\
\hline $\begin{array}{l}\text { Leaves } \\
\text { Genipinic acid }\end{array}$ & 0.172 & 0.3 & 0.468 & 0.418 & -0.368 & 0.205 & -0.176 & -0.345 & $0.656^{*}$ & -0.198 & 0.205 \\
\hline $\begin{array}{l}\text { Leaves } \\
\text { chlorogenic } \\
\text { acid }\end{array}$ & $0.776^{\star \star}$ & $0.917^{\star \star}$ & $0.832^{\star \star}$ & $0.788^{\star \star}$ & $-0.680^{*}$ & 0.279 & 0.381 & $-0.883^{\star \star}$ & $0.8810^{\star *}$ & -0.156 & 0.253 \\
\hline $\begin{array}{l}\text { Leaves } \\
\text { geniposide }\end{array}$ & 0.351 & 0.151 & 0.041 & -0.027 & -0.203 & $0.611^{*}$ & 0.458 & -0.497 & 0.212 & -0.216 & 0.334 \\
\hline $\begin{array}{l}\text { Leaves } \\
\text { aucubin }\end{array}$ & $-0.628^{*}$ & $-0.685^{\star}$ & -0.396 & -0.411 & 0.347 & -0.367 & $-0.628^{*}$ & $0.726^{\star *}$ & -0.529 & 0.140 & -0.297 \\
\hline
\end{tabular}

\subsubsection{Correlation between content of medicinal components and functional traits}

Tab. 6 shows: in overall, the content of medicinal components in root bark, trunk bark, and leaves of Eucommia ulmoides has correlation with functional traits. Where, aucubin content in root bark, trunk bark, and leaves has a good correlation with functional traits, especially with leaf dry weight, chlorophyll fluorescence parameters, leaf carbon content, root nitrogen content, root carbon nitrogen ratio, crown length ratio, branch and leaf index, followed by the correlation between root bark genipinic acid, root bark geniposide, leaf chlorogenic acid, leaf geniposide and functional traits. Significant relationship is exhibited between root bark, trunk bark and leaf aucubin content and leaf dry weight, chlorophyll fluorescence parameters, leaf carbon content, root carbon nitrogen ratio, crown length ratio, branch and leaf index; between root bark geniposide content and chlorophyll fluorescence parameters, leaf carbon content, root carbon nitrogen ratio, branch and leaf index, crown length ratio; between leaf chlorogenic acid content and root nitrogen content, branch and leaf index, petiole length, chlorophyll fluorescence parameters, root carbon nitrogen ratio; between root bark genipinic acid and leaf dry weight, petiole length, leaf carbon content, etc. The above correlation reflects that functional traits of Eucommia ulmoides can affect the content of medicinal components in root bark, trunk bark and leaves, especially the content of aucubin in root bark, trunk bark and leaves.

Tab.6 Correlation between the contents of medicinal components in root bark, trunk bark and leaves and plant functional traits 


\begin{tabular}{|c|c|c|c|c|c|c|c|c|c|c|c|}
\hline & $\begin{array}{l}\text { Root } \\
\text { bark } \\
\text { Genipinic } \\
\text { acid }\end{array}$ & $\begin{array}{l}\text { Root bark } \\
\text { Chlorogenic } \\
\text { acid }\end{array}$ & $\begin{array}{l}\text { Root bark } \\
\text { geniposide }\end{array}$ & $\begin{array}{l}\text { Root } \\
\text { bark } \\
\text { aucubin }\end{array}$ & $\begin{array}{l}\text { Trunk } \\
\text { bark } \\
\text { Genipinic } \\
\text { acid }\end{array}$ & $\begin{array}{l}\text { Trunk bark } \\
\text { Chlorogenic } \\
\text { acid }\end{array}$ & $\begin{array}{l}\text { Trunk bark } \\
\text { geniposide }\end{array}$ & $\begin{array}{l}\text { Trunk } \\
\text { bakr } \\
\text { aucubin }\end{array}$ & $\begin{array}{l}\text { Leaves } \\
\text { Genipinic } \\
\text { acid }\end{array}$ & $\begin{array}{l}\text { Leaves } \\
\text { chlorogenic } \\
\text { acid }\end{array}$ & $\begin{array}{l}\text { Leav } \\
\text { geni }\end{array}$ \\
\hline Petiole & $0.601^{*}$ & -0.016 & 0.533 & 0.522 & $0.738^{* *}$ & 0.158 & 0.413 & 0.470 & -0.367 & $-0.655^{\star}$ & $-0.1 \epsilon$ \\
\hline $\begin{array}{l}\text { Leaf dry } \\
\text { weight }\end{array}$ & $0.715^{* *}$ & -0.479 & 0.495 & $0.786^{* *}$ & 0.117 & -0.303 & 0.519 & $0.630^{*}$ & 0.290 & -0.317 & -0.51 \\
\hline $\begin{array}{l}\text { specific } \\
\text { surface }\end{array}$ & -0.088 & 0.392 & -0.565 & -0.482 & 0.070 & 0.295 & -0.16 & $-0.649^{*}$ & -0.461 & 0.296 & 0.40 \\
\hline $\begin{array}{l}\text { Chlorophyll } \\
\text { fluorescence } \\
\text { parameters }\end{array}$ & 0.389 & -0.065 & $0.669^{*}$ & $0.794^{\star \star}$ & 0.170 & -0.225 & 0.414 & $0.786^{\text {** }}$ & -0.084 & $-0.622^{*}$ & $-0.3 \varepsilon$ \\
\hline $\begin{array}{l}\text { Leaf carbon } \\
\text { content }\end{array}$ & $0.635^{\star}$ & -0.437 & $0.701^{*}$ & $0.912^{\star *}$ & 0.395 & -0.475 & 0.504 & $0.792^{* *}$ & 0.241 & -0.532 & $-0.5<$ \\
\hline $\begin{array}{l}\text { Leaf } \\
\text { nitrogen } \\
\text { content }\end{array}$ & -0.160 & 0.169 & -0.061 & -0.211 & 0.376 & 0.233 & -0.154 & -0.163 & -0.392 & -0.126 & 0.46 \\
\hline $\begin{array}{l}\text { Leaf } \\
\text { phosphorus } \\
\text { content }\end{array}$ & -0.132 & 0.457 & 0.067 & -0.052 & 0.202 & 0.402 & -0.151 & 0.017 & -0.559 & -0.415 & 0.09 \\
\hline $\begin{array}{l}\text { Root carbon } \\
\text { content }\end{array}$ & 0.072 & 0.373 & -0.352 & -0.177 & 0.101 & 0.019 & -0.041 & -0.251 & -0.248 & 0.05 & $-0.1 £$ \\
\hline $\begin{array}{l}\text { Root } \\
\text { nitrogen } \\
\text { content }\end{array}$ & 0.172 & -0.171 & -0.553 & -0.453 & 0.036 & 0.003 & 0.341 & $-0.618^{*}$ & 0.117 & $0.631^{*}$ & 0.71 \\
\hline $\begin{array}{l}\text { Root } \\
\text { phosphorus } \\
\text { content }\end{array}$ & 0.207 & -0.451 & -0.078 & -0.151 & -0.021 & -0.188 & 0.365 & -0.082 & 0.379 & 0.442 & 0.20 \\
\hline $\begin{array}{l}\text { Root } \\
\text { carbon- } \\
\text { nitrogen } \\
\text { ratio }\end{array}$ & 0.211 & -0.203 & $0.691^{*}$ & $0.707^{\star}$ & 0.252 & -0.192 & 0.065 & $0.701^{*}$ & 0.026 & $-0.691^{*}$ & $-0.6 \varepsilon$ \\
\hline $\begin{array}{l}\text { Ratio of } \\
\text { Bark }\end{array}$ & 0.565 & $-0.807^{\star \star}$ & -0.047 & 0.286 & 0.060 & -0.548 & $0.616^{*}$ & -0.005 & $0.708^{* *}$ & 0.308 & $-0.1<$ \\
\hline $\begin{array}{l}\text { Crown } \\
\text { length ratio }\end{array}$ & -0.124 & 0.442 & $-0.580^{*}$ & $-0.644^{*}$ & 0.047 & 0.491 & -0.032 & $-0.733^{* \star}$ & -0.293 & 0.323 & 0.64 \\
\hline $\begin{array}{l}\text { Leaflet } \\
\text { Index }\end{array}$ & -0.025 & 0.100 & $-0.764^{\star \star}$ & $-0.640^{*}$ & -0.046 & -0.105 & 0.047 & $-0.768^{* *}$ & 0.141 & $0.671^{*}$ & 0.42 \\
\hline
\end{tabular}

\section{Discussion}

\subsection{The genuineness of Eucommia ulmoides from Guizhou and its main influencing factors}

This study shows that genipinic acid content of Eucommia ulmoides in type B (intensity karst rocky desertification area) (18.89mg/g), type D (moderate karst rocky desertification area) $(19.15 \mathrm{mg} / \mathrm{g})$ is higher compared to normal landforms of Hunan Zhuzhou $(7.25 \mathrm{mg} / \mathrm{g})$ and Zhejiang Hangzhou (9.9mg/g) at the same latitude (Qing et al., 2018), which is also higher compared to normal landforms of Hebei Anguo (7.95mg/g), Henan Luoyang (11.33mg/g), Henan Kaifeng (10.00mg/g), Beijing (10.03mg/g), Jiangsu Xiangshui (10.97mg/g), Sichuan Guangyuan (9.58mg/g), Shanxi Yuncheng (9.88mg/g), etc. at high latitude. However, the potential and mild rocky desertification areas of type A $(6.20 \mathrm{mg} / \mathrm{g})$ and type $\mathrm{C}(3.77 \mathrm{mg} / \mathrm{g})$ have lower content than the above areas. This study shows that genipinic acid content in trunk bark of Eucommia ulmoides is higher in type A (17.09mg/g), type C (22.09mg/g), type D (25.88mg/g) than in Hunan Jianghua (14.23mg/g), Xupu (14.86mg/g), Yuanling (15.32 mg/g) of the same latitude (Cai,2014), which is comparable to that of Hunan Baojing $(20.46 \mathrm{mg} / \mathrm{g})$ and Shimen $(18.73 \mathrm{mg} / \mathrm{g})$, but much higher compared to high-latitude Shaanxi Lueyang $(7.15 \mathrm{mg} / \mathrm{g})$ and Ankang $(3.54 \mathrm{mg} / \mathrm{g})$. The above analysis indicates that Guizhou's natural geographical characteristics exert an important influence on genipinic acid content of Eucommia ulmoides, which is generally higher compared to the normal landform. In this study, trunk bark chlorogenic acid content of Eucommia ulmoides in type A (2.21mg/g) and type $\mathrm{C}$ $(2.38 \mathrm{mg} / \mathrm{g})$ was higher compared to Hunan Jianghua $(1.35 \mathrm{mg} / \mathrm{g})$, Xupu $(1.48 \mathrm{mg} / \mathrm{g})$, Baojing $(1.72 \mathrm{mg} / \mathrm{g})$, Yuanling $(1.38 \mathrm{mg} / \mathrm{g})$, Shimen $(1.59 \mathrm{mg} / \mathrm{g})$ of the same latitude (Cai,2014), which was also higher compared to Shaanxi Lueyang $(1.20 \mathrm{mg} / \mathrm{g})$ and Ankang (1.15mg/g) of high latitude. Type B and D had comparable content to the above-mentioned regions. The leaf chlorogenic acid contents of Eucommia ulmoides in the three habitat types $B$, $C$, and $D$ were respectively $16.37 \mathrm{mg} / \mathrm{g}, 11.21 \mathrm{mg} / \mathrm{g}, 9.81 \mathrm{mg} / \mathrm{g}$, which was comparable to Hunan Jianghua (11.03mg/g), Xupu (10.21mg/g) , Baojing (12.44mg/g), Yuanling $(11.80 \mathrm{mg} / \mathrm{g})$, Shimen $(9.22 \mathrm{mg} / \mathrm{g})$, Cili $(15.01 \mathrm{mg} / \mathrm{g})$ of the same latitude, while the content in type B, C, and D was comparable to that of high-latitude Lueyang $(11.54 \mathrm{mg} / \mathrm{g})$, Ankang $(12.85 \mathrm{mg} / \mathrm{g})$. It shows that Guizhou's natural geographical characteristics also have a major influence on chlorogenic acid content, which is higher than or comparable to that of normal landforms in overall. In this study, aucubin content in trunk bark of Eucommia ulmoides in type A $(14.66 \mathrm{mg} / \mathrm{g})$, type D $(12.59 \mathrm{mg} / \mathrm{g})$ is comparable to that of Hunan Jianghua (14.84mg/g), Xupu (15.71mg/g), Baojing (10.91mg/g), Yuanling (14.32mg/g), Shimen $(16.73 \mathrm{mg} / \mathrm{g})$ of the same latitude ${ }^{[21]}$, but much higher than that of high-latitude Shaanxi Lueyang (3.75mg/g), Ankang (2.11 mg/g). Leaf aucubin 
content in type A (12.36mg/g), type D (8.88mg/g) was higher compared to Hunan Jianghua (2.64mg/g), Xupu (2.68mg/g), Baojing (3.3 mg/g), Yuanling $(2.59 \mathrm{mg} / \mathrm{g})$, Shimen $(1.76 \mathrm{mg} / \mathrm{g})$, and Cili $(4.65 \mathrm{mg} / \mathrm{g})$ of the same latitude, which was far higher compared to high-latitude Shaanxi Lueyang $(1.51 \mathrm{mg} / \mathrm{g})$, Ankang $(1.23 \mathrm{mg} / \mathrm{g})$, while that of type B $(3.15 \mathrm{mg} / \mathrm{g})$ and type $\mathrm{C}(1.18 \mathrm{mg} / \mathrm{g})$ was comparable to the above regions. The above reflects that aucubin content in trunk bark and leaves of Eucommia ulmoides produced in Guizhou is generally higher compared to other regions. Studies have shown that in Zunyi and Bijie of Guizhou, genipinic acid content in trunk bark of Eucommia ulmoides is $24.29 \mathrm{mg} / \mathrm{g}$ and $24.92 \mathrm{mg} / \mathrm{g}$ respectively, aucubin content is $20.84 \mathrm{mg} / \mathrm{g}$ and $28.42 \mathrm{mg} / \mathrm{g}$, respectively; leaf genipinic acid content is $6.91 \mathrm{mg} / \mathrm{g}, 5.63 \mathrm{mg} / \mathrm{g}$, respectively, aucubin content is $3.84 \mathrm{mg} / \mathrm{g}, 2.48 \mathrm{mg} / \mathrm{g}$, respectively (Cai,2014). In Zunyi, the leaf genipinic acid content of Eucommia ulmoides is $8.97 \mathrm{mg} / \mathrm{g}$, aucubin content is $29.21 \mathrm{mg} / \mathrm{g}$ (Qing et al., 2018). The results of this study indicate that genipinic acid, aucubin contents in trunk bark and leaf of the four types of Eucommia ulmoides exhibit basically consistent law with the research results of the two researchers in different periods. This implies that content of medicinal components of Eucommia ulmoides produced in Guizhou has relatively stable spatial and temporal distribution.

The above analysis reveals that, as a whole, the content of medicinal components in Eucommia ulmoides produced from Guizhou is generally higher than that of other regions (including regions of the same latitude and high latitude), with only some regions slightly lower compared to other regions, and the temporal and spatial distribution is relatively stable. Meanwhile, a close relationship is exhibited with natural regional characteristics of Guizhou. Studies have shown that effective ingredient content and pharmacological activity of Eucommia ulmoides leaves differ between different origins, which may be related to the content of metal elements(Peng et al., 2011). Soil alkali-hydrolyzable nitrogen exerts a great effect on the accumulation of aucubin, genipinic acid and chlorogenic acid in the bark of Eucommia ulmoides, followed by rapidly available potassium and organic matter (Cai,2014). This study also suggests that different elements in different parts of Eucommia ulmoides have significantly different enrichment coefficients between different habitats. These studies indicate that natural regional characteristics will impact content of medicinal components in Eucommia ulmoides. At the same time, based on the correlation between the content of medicinal components in Eucommia ulmoides from Guizhou and the habitat, this study shows that soil physical and chemical indexes and metal element contents in habitats of Eucommia ulmoides exert different effects on the contents of medicinal components in root bark, trunk bark and leaves of Eucommia ulmoides. In particular, leaf chlorogenic acid, trunk bark aucubin, root bark geniposide, root bark aucubin, and trunk bark genipinic acid are particularly affected by soil physical and chemical indexes and the content of metal elements. Moreover, this study indicates that the functional traits of Eucommia ulmoides can affect the content of medicinal components in root bark, trunk bark and leaves, with particular impact on content of aucubin in root bark, trunk bark and leaves. The above suggests that Guizhou's natural regional characteristics significantly affect genuineness of Eucommia ulmoides. Therefore, high and stable content of medicinal ingredients of Eucommia ulmoides from Guizhou is its primary characteristic of genuineness, and such genuineness is inseparable from the natural regional characteristics of Guizhou karst plateau mountain.

\subsection{Implications for afforestation}

This study shows that genipinic acid content is the highest in the root bark, which is much higher than that in trunk bark and leaves. The genipinic acid content in the root bark of the four habitat types is ranked in descending order as $73.62 \mathrm{mg} / \mathrm{g}$ in type $\mathrm{D}, 46.15 \mathrm{mg} / \mathrm{g}$ in Type $\mathrm{C}, 39.85 \mathrm{mg} / \mathrm{g}$ in type $\mathrm{A}, 32.79 \mathrm{mg} / \mathrm{g}$ in type $B$, while type $D$ has a higher content than the other 3 types (Fig. 6), showing better root functional traits (Fig. 5). Genipinic acid content in root bark is negatively correlated with soil $\mathrm{pH}$ value and soil $\mathrm{Ca}$ (Tab. 5). Type $\mathrm{D}$ habitat is a mild rocky desertification area, where genipinic acid content in the root bark is positively correlated with root functional traits (Tab. 6). There is no report on the content of medicinal components in root bark. Therefore, if genipinic acid is deemed as the target medicinal component, root bark is the best medicinal resource part of Eucommia ulmoides, and it is best to cultivate the medicinal root bark in type $\mathrm{D}$ habitat, followed by type $\mathrm{C}$ habitat and type $\mathrm{A}$ habitat, but it is best not to cultivate root bark in type $\mathrm{B}$ habitat for the purpose of obtaining genipinic acid. This study shows that the content of chlorogenic acid is the highest in the leaves. The leaf chlorogenic acid content of the four habitat types of Eucommia ulmoides is ranked in descending order as $16.37 \mathrm{mg} / \mathrm{g}$ in type $B, 11.21 \mathrm{mg} / \mathrm{g}$ in type $\mathrm{C}, 9.81 \mathrm{mg} / \mathrm{g}$ in type $\mathrm{D}$, and $4.37 \mathrm{mg} / \mathrm{g}$ in type $A$, while type $B$ has a higher content than the other 3 types (Fig. 6), which is consistent with the study results $(\mathrm{Xu}, 2015)$ that the content of chlorogenic acid in Eucommia ulmoides is higher in leaf than in bark. Type $B$ has worse leaf functional traits than type A, type $D$, which is because type $B$ habitat is an intensity rocky desertification area (Fig. 5). When faced with stress, plant secondary metabolites have greater defense benefits, with more secondary metabolites produced [41] (BARTO et al., 2005). Chlorogenic acid content is extremely significantly positively correlated with soil organic matter, total phosphorus, rapidly available phosphorus, total nitrogen, alkali-hydrolyzable nitrogen, soil moisture, soil Mn, soil Zn. Soil physical and chemical indexes greatly impact the accumulation of leaf chlorogenic acid content in Eucommia ulmoides, and type B habitat has better quality in overall (Fig. 3). Leaf functional traits are mostly negatively correlated with leaf chlorogenic acid content (Tab. 6). Therefore, if chlorogenic acid is taken as the target medicinal component, it is best to cultivate Eucommia ulmoides leaves on type B habitat, followed by cultivation of leaves in type $C$ and type $D$ habitats. This study reveals that geniposide content is the highest in trunk bark. The geniposide content in trunk bark of the four types of Eucommia ulmoides is ranked in descending order as $7.81 \mathrm{mg} / \mathrm{g}$ in type $\mathrm{D}$,

$3.43 \mathrm{mg} / \mathrm{g}$ in type C, $1.32 \mathrm{mg} / \mathrm{g}$ in type A, $0.88 \mathrm{mg} / \mathrm{g}$ in type B (Fig.6). The geniposide content in trunk bark is mostly negatively correlated with soil physical and chemical indexes (Tab. 5), showing a good correlation with functional traits (Tab. 6). Hence, if geniposide is taken as the target medicinal component, it is best to cultivate trunk bark of Eucommia ulmoides in type $D$ habitat, followed by type $C$, and then type $A$ and type $B$ habitats. This study suggests that aucubin content is the highest in the root bark, and aucubin content in the root bark of the four types of Eucommia ulmoides is ranked in descending order as $47.99 \mathrm{mg} / \mathrm{g}$ in type $\mathrm{D}, 45.19 \mathrm{mg} / \mathrm{g}$ in type $\mathrm{A}, 22.66 \mathrm{mg} / \mathrm{g}$ in type $\mathrm{C}, 19.57 \mathrm{mg} / \mathrm{g}$ in type B (Fig. 6). The aucubin content in root bark is positively correlated with total potassium and soil bulk density, showing a good correlation with functional traits. Therefore, if aucubin is taken as the target medicinal component, it is best to cultivate root bark of Eucommia ulmoides in type $\mathrm{D}$ habitat, followed by type $\mathrm{A}$ habitat, and then type $\mathrm{C}$ and type $\mathrm{B}$ habitats. The above analysis indicates important implications of this study for afforestation. That is, in the process of Eucommia ulmoides afforestation, comprehensive consideration should be given to habitat, functional traits, medicinal component content of Eucommia ulmoides and their correlation. To acquire different target medicinal components, it is possible to implement classified afforestation and classified management, "plant according to the environment and conduct field survey of medicines", thus making the best use of the land and medicine to achieve the maximum economic value, social value and ecological value.

\section{Conclusion}


Eucommia ulmoides plantations in Guizhou Province can be divided into 4 types, namely, Type A with low altitude, low, medium and high temperature rain slope latitude mixing, short sunshine, Type B with medium altitude, low latitude and longitude, high temperature rain, positive oblique steep slope, medium sunshine, Type $\mathrm{C}$ with medium altitude, low latitude and longitude, moderate high temperature rain, gentle deflection steep slope in shady side and sunny side, medium sunshine, Type D with high altitude, low longitude and latitude, low temperature and moderate rain, positive gentle slope, long sunshine. Habitat quality differs between the 4 types of Eucommia ulmoides plantations, whose indexes display good correlation with the contents of genipinic acid, chlorogenic acid, geniposide and aucubin in root bark, trunk bark, and leaves. Affected by the topography and landforms, the average forest density and different climate, the four types of Eucommia ulmoides plantation communities have slightly different shrub-grass species diversity indexes. A good correlation is shown between the content of genipinic acid, chlorogenic acid, geniposide, aucubin in root bark, trunk bark and leaves of Eucommia ulmoides and species diversity index of the shrub-grass layer of the community. Among the 4 types of Eucommia ulmoides plantations, most of the functional traits of Eucommia ulmoides exhibit significant or extremely significant differences, showing significant or extremely significant correlation with the content of genipinic acid, chlorogenic acid, geniposide and aucubin in root bark, trunk bark and leaves. Plants adapt to the environment through a combination of a series of functional traits, which reflects the plant's adaptation to the environment and resource utilization strategies. It is possible to adjust the functional traits of Eucommia ulmoides to let it better adapt to the habitat of the planting area, thereby further increasing the content of medicinal components in root bark, trunk bark and leaves of Eucommia ulmoides. For the 4 types of Eucommia ulmoides plantations, root bark has significantly higher contents of genipinic acid and aucubin than trunk bark and leaves. This study provides a new idea for seeking the medicinal resource site of Eucommia ulmoides, which carries important theoretical reference significance for cultivation of Eucommia ulmoides in Guizhou, cultivation of target medicinal components and comprehensive development and utilization of resources

\section{Declarations}

\section{Acknowledgements}

The authors would like to thank the editors and anonymous reviewers for their valuable comments and suggestions.

\section{Funding}

This work is supported by the 13th Five-year National Key Research and Development Plan (2016YFC0502604), National Natural Science Foundation of China (51868008,51978187), Construction Program of Biology First-class Discipline in Guizhou (GNYL[2017]009), Guizhou provincial first-class major (biological science) project (Education department of Guizhou province [2019] 46), the Project of Promoted Innovation of Colleges and Universities of Guizhou Province (Qian Jiao He Collaborative Innovation [2014]01).

\section{Author information}

Affiliations

Guizhou University, The Key laboratory of Plant Resource Conservation and Germplasm Innovation in Mountainous Region (Ministry of Education),

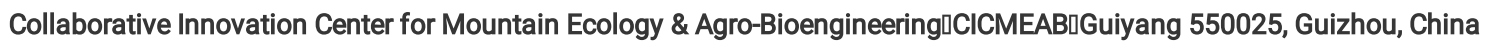

Changjiang Qian, Zongsheng Hung, Lifei Yu \& Lingbin Yan

College of Biological Sciences,Guizhou Education University, Guiyang 550018, Guizhou, China

Changjiang Qian, Rongrong Zhang, Jia Li, Xun Liu, \& Yuhong Fu

\section{Contributions}

Changjiang Qian:Research project design,investigation,Determination and Analysis of

Experimental Data,Writing of the original draft

Rongrong Zhang and Jia Li:Determination of experimental data

Zongsheng Hung:Logical guidance and revision of papers

Lifei Yu:Research programme guidance, paper content guidance

Xun Liu,Lingbin Yan and Yuhong Fu:Guidance for the determination of experimental samples

Corresponding author

Lifei Yu

Ethics declarations

Ethical approval

Not applicable 


\section{Consent to Participate}

Not applicable

\section{Consent to Publish}

Written informed consent for publication was obtained from all participants.

\section{Competing interests}

The authors declare that they have no competing interest.

\section{Data availability}

The experimental data and materials are available from the first author upon reasonable request.

\section{References}

1. Bai MM, Shi W, Tian JM, Zhang KJ Jang HK,Ya NS, Young HK and Gao JM(2015)Soluble Epoxide Hydro-lase Inhibitory and Anti-inflammatory Components from the Leaves of Eucommia ulmoides Oliver (Duzhong). J. Agric. Food Chem., 63 (8): 2198-2205.

2. Bao SD (1999) Soil agrochemical analysis (third edition).China Agriculture Press,Beijing.

3. Barto E K, Cipollin ID (2005) Testing the optimal defense theoryand the growth-differentiation balance hypothesis in Arabidopsis thaliana. Oecologia, 2005 (146): 169-178.

4. Cai P, Liu CY, Liang XJ, Xiao J, Wan D, Zhang S H (2014) Grey Correlation Degree Analysis Between Active Ingredientsin Barks or Leaves of Eucommiae Cortex and Environmental Factors in Their Habitats. Chin. J. Exp. Tradit. Med. Form., 20 (23):10-14.

5. Cai YL (1996) Preliminary Research Ecological Reconstruction in Karst Mountains Poverty Areas of Southwest China.Adv. Earth Sci. 11 (6): $602-606$.

6. Chen N, Sun X,Song X,Lu BL and Chen L (2015) Industrialization Development Status,Existing Problem and Suggestions of Genuine Medicinal Materials Eucommia ulmoides in Guizhou. Tillage Cultiv., 2015 (1): 33-34, 51.

7. Du HY and Du QX (2020) Foundation, problems and countermeasures of Eucommia ulmoides industry high-quality development in China. Nonwood For. Res., 38 (1): 1-10.

8. Du HY (2003) The Progress in Research of the Active Component from Eucommia ulmoides and Its Pharmaceology. Nonwood For. Res., 2003 (2): 58-61, 82.

9. Du HY, Hu WZ, Liu PF, Du LY (2016) Some strategies on bottleneck problems of Eucommia ulmoides industrial upgrading in China.Nonwood Forest Res.,34 (1): 176-180.

10. Du XL,Zhu GP, Yan WD, Liu PF, Zhu JL (2016) Exploration for high density cultivation models for harvesting leaf, bark and wood in Eucommia ulmoides[J].Nonwood Forest Res., 34 (3): 1-7.

11. Fang C, Chen LY, He MZ, Luo YY, Zhou M J, Zhang N, Yuan JF, Wang HL and Xie YY (2019) Molecular mechanistic insight into the anti-hyperuricemic effect of Eucommia ulmoides in mice and rats. Pharm. Biol., 57 (1): 112-119.

12. Fu H, Bai X, Le L,Tian D, Gao H, Qi LX, Hu KP (2019) Eucommia ulmoides Oliv. Leaf Extract Improves Erectile Dysfunction in Streptozotocin-Induced Diabetic Rats by Protecting Endothelial Function and Ameliorating Hypothalamic-Pituitary-Gonadal Axis Function. Evid. Based Complementary Altern. Med., 2019: 1-12.

13. He SZ, Xu WF, Huang M, Wei SH, Zhang TL and Wang Y (2005) Study on the species and distribution of traditional Chinese medicine resources in Guizhou[J].World J. Sci. technol. 2005(2): 95-102, 120.

14. Jan Lepš and Petr Šmilauer (2003) Multivariate Analysis of Ecological Date using CANOCOTM. Cambridge university press,Česko.

15. Jiao HL (2016) Study on the Extraction and Quality of Eucommia Ulmoides Seed Oil.Henan Univ. Technol.

16. Lee GH, Lee MR, Lee HY, Kim SH, Kim HK, Kim HR and Chae HJ (2014) Eucommia ulmoides Cortex, Geniposide and Aucubin Regulate Lipotoxicity through the Inhibition of Lysosomal BAX. PLOS ONE, 9 (2): 1-14.

17. Li FD,Du HY $₫ 2001 \rrbracket$ Eucommia ulmoides Oliver.China Press of Tradit. Chinese Med.,Beijing.

18. Lin KQ, Li Y, Zou BJ, Zhang TY ,He XZ, Zhao DG $₫ 2016 \otimes$ Genetic Diversity and Phylogenetic Relationship of Cultivated Eucommia ulmoides Olive in Guizhou by SSR. Genomics Appl. Biol., 2016(6):1521-1529.

19. Liu CY, Li Q, Du H Y, Zhu JLه2010囚 Effects of formula fertilization on the content of main activecomponents from Eucommia ulmoides male flower.J. Central South Univ. For. \& Technol., 30 (8):29-34

20. Liu RH, Tang FR, Chen LY, Shao F, Li YY, Zhang ZL and Huang HL (2015) Comparison of Contents of Five Effective Components in Eucommiae Folium from Different Areas. Chin. J. Exp. Tradit. Med. Form., 21 (18): 316-323.

21. Lou LJ, Chen BQ, Du HY, Fu JM, Du LY and Li X (2011) Protection effects of Eucommia ulmoides male flower tea oncarbon tetrachloride induced liver injury in mice. J. Henan Univ. (Med. Sci. ), 30(1): 24-26.

22. Peng HM and Li XS (2013) Pharmacological Research and Application of Duzhong. China. J. Chin. Med., 28 (176): $72-73$.

23. Peng JN, Peng XJ, Li YB, Yu L, Li QS (2011) Analysis on the Content and Variation Trends of Metalic Elements in Eucommia ulmoides Oliv.Samples from Different Areas. Guangdong Trace Elem. Sci., 2011(4): 46-49. 
24. Qing J, Wei YX, Wang D H, Wang L, Liu PF, Du HY, Du QX (2018) Study on Genetic Variation of Main Active Components in Leaves of Eucommia ulmoides. Acta Botanica Boreali-Occidentalia Sinica, 38 (2): 316-323.

25. Sugawa H, Ohno RI, Shirakawa JI, Nakajima A, Kanagawa A, Hirata T, Ikeda K, Moroishi N, Nagaia N and Nagai R (2016) Eucommia ulmoides extracts prevent the formation of advanced glycation end products. Food \& Funct., 7 (6): 2566-2573.

26. Sun YR,Dong JX and Wu SG (2004) Studies on Chemical Constituents from Eucommia ulmoides Oliver. J. Chin. Med. Mater., 27 (5): $341-343$.

27. Hirata T,Kobayash T, Wada A, UedaT, Fujikawa T, Miyashita H, Ikeda T, Tsukamoto S and Nohara T (2011) Antiobesity compounds in green leaves of Eucommia ulmoide.Bioorg. Med. Chem. Lett., 21 (6): 1786-1791.

28. Wang DL (2003) Study on Karst Rocky Desertification formation process and Its control Technology.Nanjing:Nanjing For. Univ.

29. Wang JY, Yuan Y, Chen XJ, Fu SG, Zhang L, Hong YL,You SF and Yang YQ (2016) Extract from Eucommia ulmoides Oliv.ameliorates arthritis via regulation of inflammation, synoviocyte proliferation and osteoclastogenesis in vitro and in vivo. J. Ethnopharmacol, 194 (2016): 609-616.

30. Wang WC, Zhang XZ (2017) Identification of the Sex-Biased Gene Expression and Putative Sex-Associated Genes in Eucommia ulmoides Oliver Using Comparative Transcriptome Analyses. Mol. (Basel, Switzerland), 22(12):56-64.

31. Wang XN (2008) Study on Correlation between contents of flavonoid in Eucommia leaves and factors of soil. Guiyang :Guizhou Norm. Univ.

32. Wu GH (2015) Study on NMR fingerprint of Eucommia ulmoides Oliv.Guiyang:Guizhou Univ.

33. Xiang H (2016) Study on extraction technique and function of active components in Eucommia ulmoides leaves from Hanzhong.Hanzhong:shaanxi Univ. Technol.,

34. Xu Y (2015) The research on the material basis of Genuineness eucommia ulmoides medicina.chengdu:Chengdu Univ. Technol.

35. Yang MD (1990) On the Fragility of the Karst Environment. Yunnan geogr. Environ. Res., $1: 21-29$.

36. Zhang AL, Ma YT,Zhao DY, Gao JM,Zhang KJ (2009) Study on Effects of Seasonal and Regional Differences on Secondary Metabolites of Eucanm ia ulnoides Oliv. Leaves. Chem. Ind. For. Prod., 29(5): 104-108.

37. Zhang JL, Xu H (2019) Research Trends of Survey Methods for Forest Biomass Estimation Based on Remote Sensing.J.Southwest For. Univ.(Nat. Sci.)., 39 (04): 166-173.

38. Zhang JT (2004) Quantitative ecology. Science Press,Beijing.

39. Zhang KJ, Ma XH, Ma M, Wang L and Zhang T (1999) A Study on dynamics accumulation of metabolites during the growth of Eucommia ulmoides leaves.Sci. Silva. Sin., 35(2): 18-23.

40. Zhu M and Sun R (2018) Eucommia ulmoides Oliver: A Potential Feedstock for Bioactive Products. J. Agric. Food Chem., 66 (22): $5433-5438$.

41. Zhu ZT (2019) The healthy development of Eucommia ulmoides industry has a long way to go- Interview with Li Zhiwei, Deputy Secretary General of China Forestry Industry Federation and leader of the drafting group of the National Development Plan for Eucommia ulmoides Industry (2016-2030). China For. Ind., 10: 10-17.

\section{Figures}

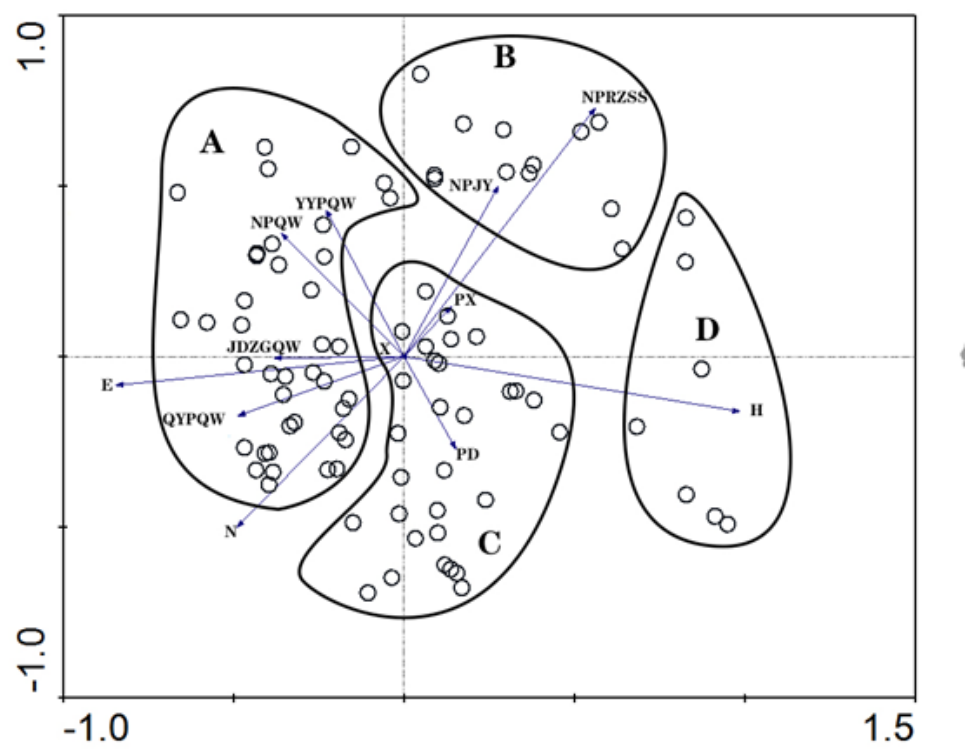

\section{Figure 1}

RDA ranking map of Eucommia ulmoides plantations survey points in Guizhou Note: The horizontal axis is longitude and altitude value, the vertical axis is temperature and rainfall; o: represents the investigation point of Eucommia ulmoides plantation, $\mathrm{H}$ : altitude; E:Iongitude; N: latitude; NPJY: Average annual rainfall; NPQW: annual mean temperature; JDZGQW: Extreme maximum air temperature; QYPQW: July average temperature; YYPQW: January average temperature; NPRZSS: annual mean sunshine hours; YX: lithology; PD: slope; PX:slope direction. 


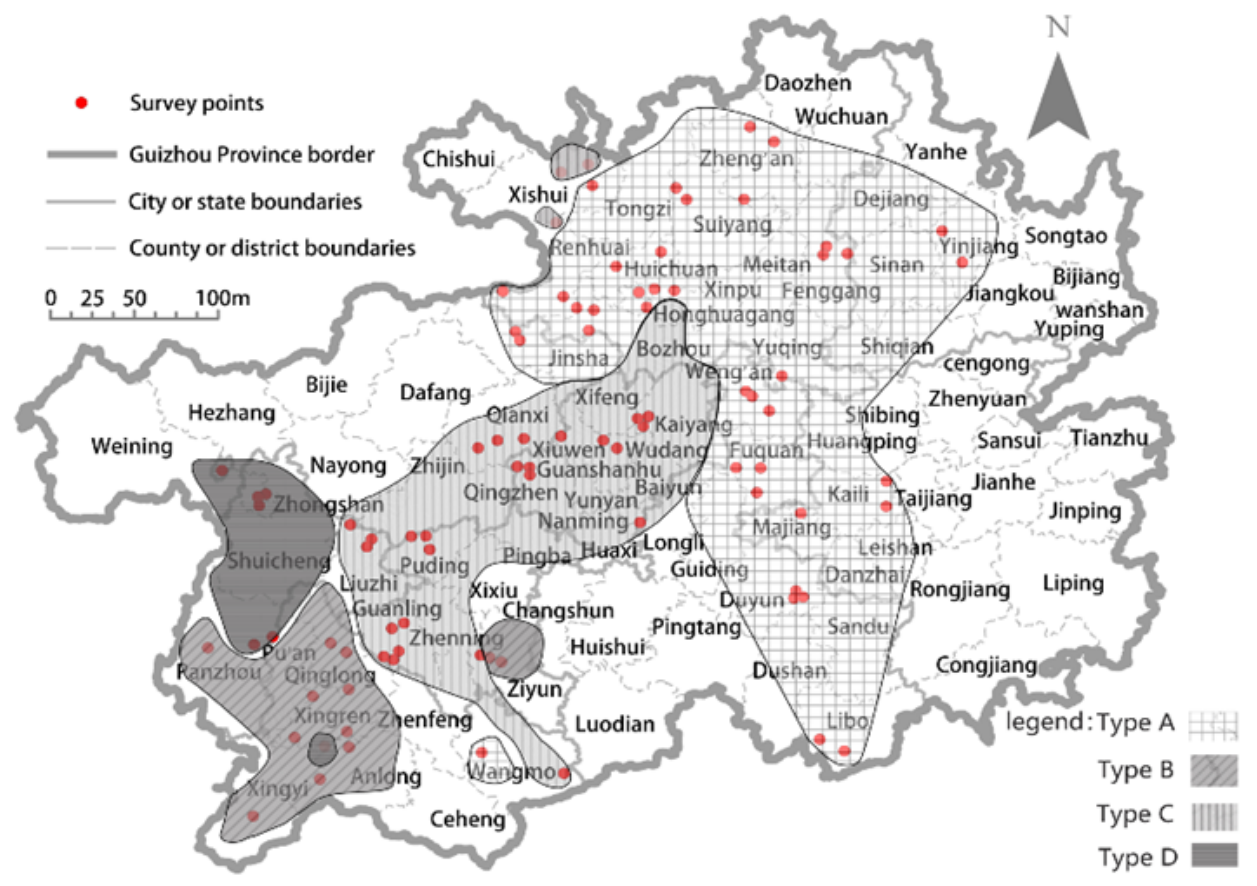

Figure 2

Regional map of four types of Eucommia ulmoides plantation in Guizhou Note: The designations employed and the presentation of the material on this map do not imply the expression of any opinion whatsoever on the part of Research Square concerning the legal status of any country, territory, city or area or of its authorities, or concerning the delimitation of its frontiers or boundaries. This map has been provided by the authors.
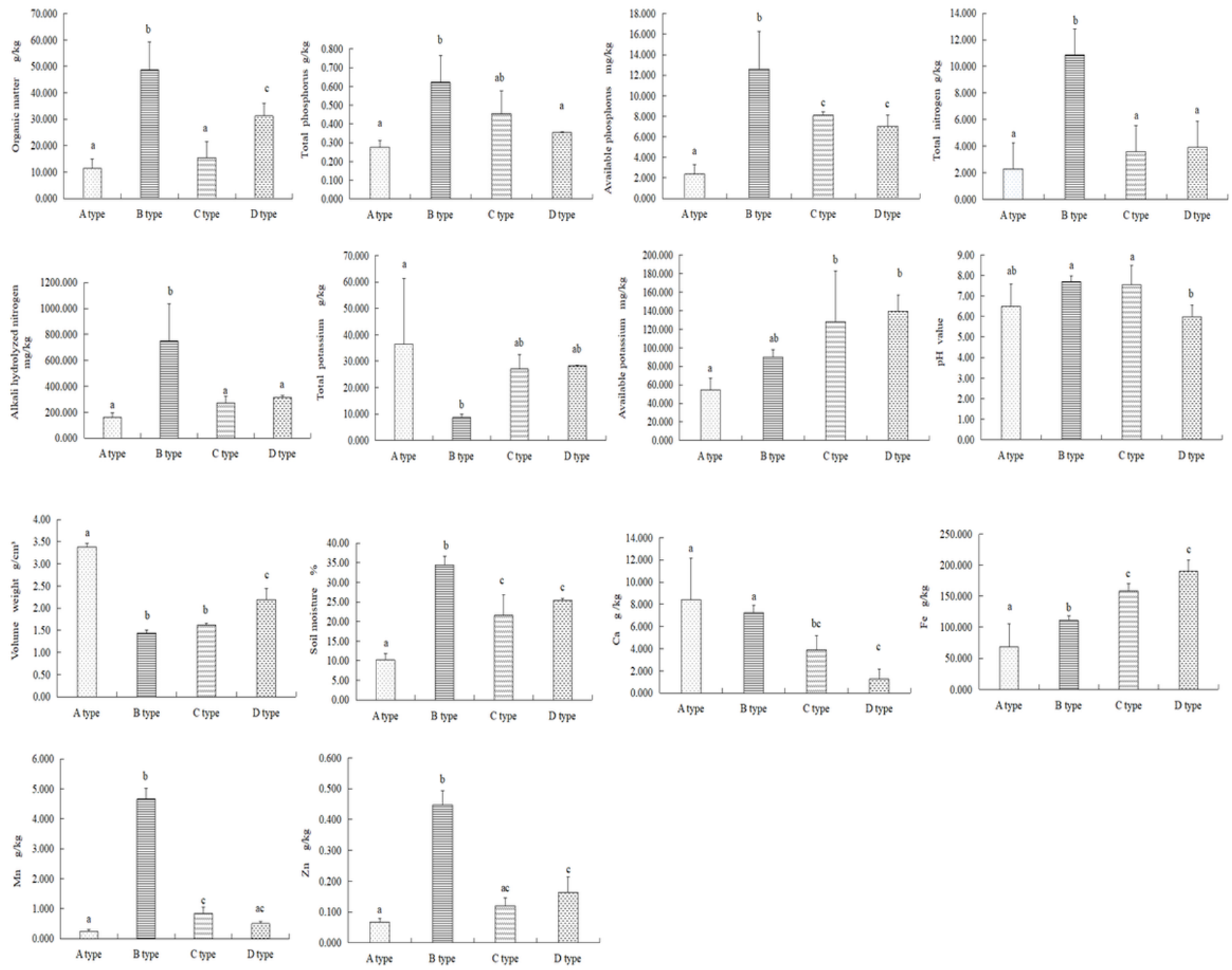
Figure 3

Soil physical and chemical properties and metal element contents of four types of Eucommia ulmoides plantations in Guizhou Note: Different lowercase letters in each figure indicate significant differences( the same below )
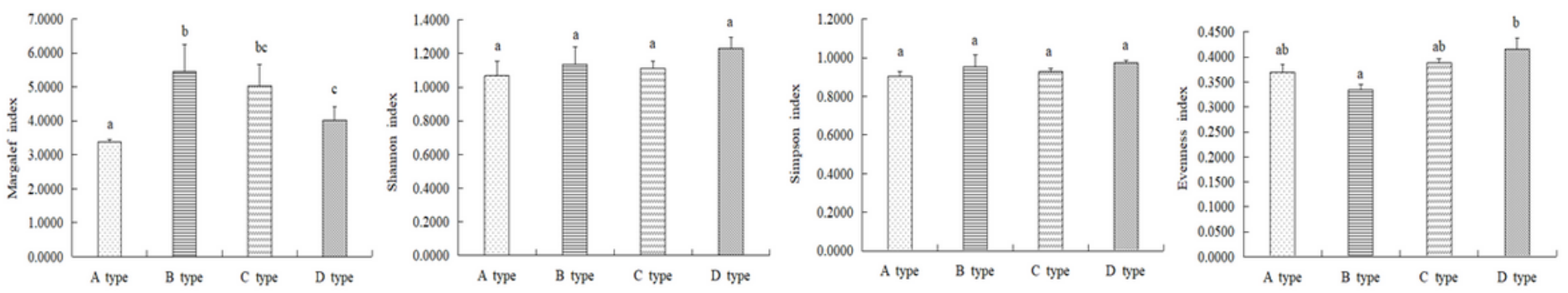

Figure 4

Community diversity index of shrub layer in four types of Eucommia ulmoides plantations
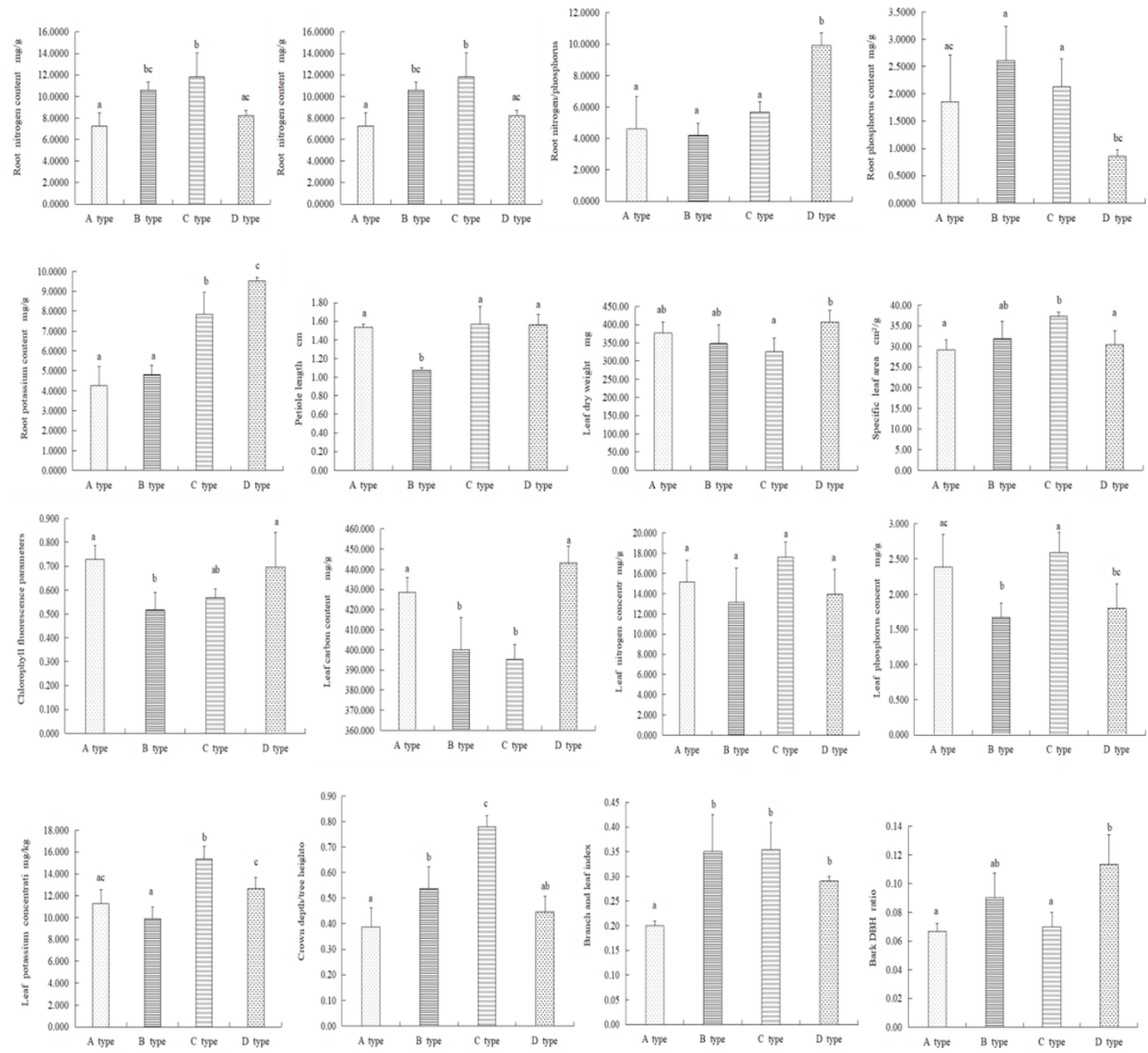

\section{Figure 5}

Functional traits of Eucommia ulmoides in four types of Eucommia ulmoides plantations Note: Bark DBH ratio $=$ bark thickness $/ \mathrm{DBH}$ at $\mathrm{DBH}$, branch index $(\mathrm{BNI})=(\mathrm{W}) /(\mathrm{W})$, crown length $=($ tree height-high under branch $) /$ tree height . 

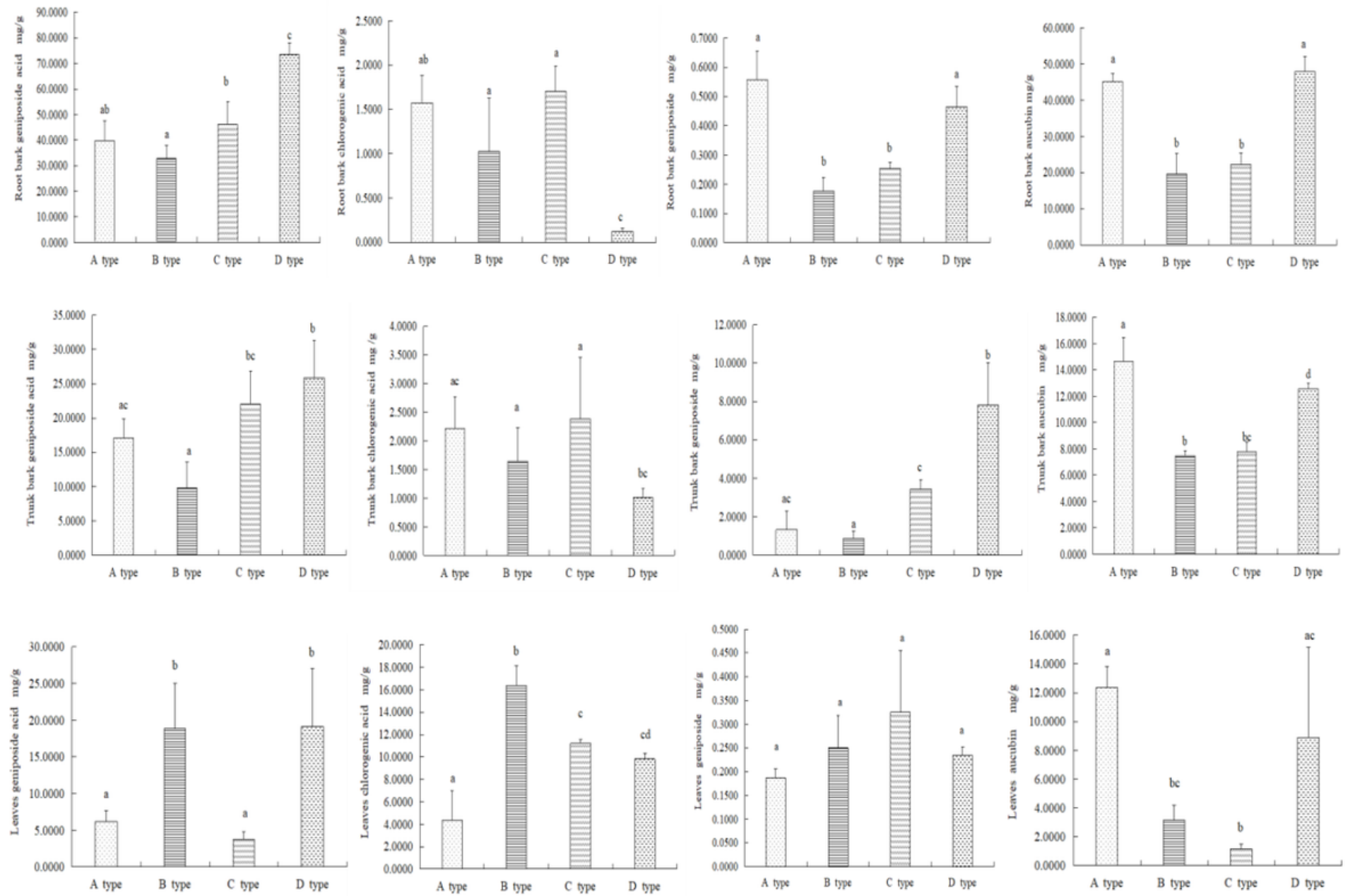

Figure 6

Average contents of medicinal components in root bark, trunk bark and leaves of Eucommia ulmoides in four types of Eucommia ulmoides plantations 